\title{
Comparison of benthic foraminifera and macrofaunal indicators of the impact of oil-based drill mud disposal
}

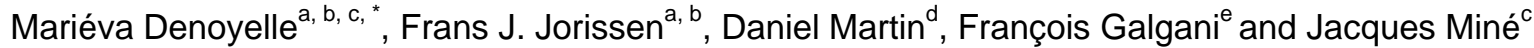 \\ a Laboratory of Recent and Fossil Bio-Indicators, UPRES EA 2644 BIAF, Angers University, 2 Bd \\ Lavoisier, 49045 Angers, France \\ ${ }^{b}$ LEBIM, lle d'Yeu, France \\ ${ }^{c}$ TOTAL S.A., DGEP/HSE-ENV, 2 place Jean Millier, 92078 Paris la Défense Cedex, France \\ d Centre d'Estudis Avançats de Blanes (CEAB-CSIC), Carrer d'accés a la Cala Sant Francesc 14, \\ 17300 Blanes (Girona), Catalunya, Spain \\ e IFREMER Corse, Imm Agostini, ZI Furiani, 20600 Bastia, France \\ *: Corresponding author : Mariéva Denoyelle, Tel.: +33 2417354 08; fax: +33 2417353 52, email address : \\ marieva.denoyelle@etud.univ-angers.fr \\ Frans J. Jorissen : frans.jorissen@univ-angers.fr \\ Daniel Martin : dani@ceab.csic.es \\ François Galgani : francois.galgani@ifremer.fr \\ Jacques Miné : jacques.mine@total.com
}

\begin{abstract}
:
We compare foraminifera and macrofauna as bio-indicators of oil-based drill mud disposal site off Congo. The most polluted sites are characterized by poor faunas, dominated by some very tolerant taxa. Slightly further from the disposal site, there is an area with strongly increased densities, heavily dominated by opportunistic taxa. Still further, macrofauna appears to be similar to that at the reference area, but the foraminiferal meiofauna still suggests a slight environmental perturbation. The foraminiferal FIEI index, based on the species distribution in the study area, appears to be more discriminative than the macrofaunal ITI index, based on a priori definitions of the trophic guilds of the various taxa. Our comparative approach allows us to point out the benefits of (1) the use of macrofauna and foraminifera together and (2) the definition of the species groups used in biotic indices on the basis of observations made directly in the study area.
\end{abstract}




\section{Introduction}

Offshore oil drilling activities may cause environmental perturbation on the sea floor, due to the construction of drilling platforms, to oil leakage, or to the disposal of drill cuttings with adhering oil- or water based drill mud. In order to have an idea of the impact of these activities on the organisms inhabiting the sea floor ecosystems, different bio-indicators are used. These bio-indicators do not reveal the presence or impact of specific pollutants, but give an integrated picture of the impact of all pollutants and physical disturbances on the ecosystem. They can be used to describe the geographical extent and the severity of environmental impact, but also to follow the recovery after cessation of drilling activities. Usually, benthic macrofauna and/or meiofauna is used to monitor drill mud disposal (e.g. Davies et al., 1984; Dicks et al., 1988; Gray et al., 1990; Daan et al., 1994; Olsgard and Gray, 1995; Shimmield et al. 2000; Gage, 2001; Grant and Briggs, 2001; Borja et al., 2003; Breuer et al., 2004; Dalmazzone et al., 2004; Durrieu and Bouzet, 2004; Muxika et al., 2005; Durrieu at al., 2006; Gass and Roberts, 2006; Flaten et al., 2007; Olsen et al., 2007). The distributional patterns of macrofauna and meiofauna around oil drilling platforms resemble the patterns found around other point sources of pollution (Dalmazzone et al., 2004; Parr et al., 2007; Schaanning et al., 2008; Venturini et al., 2008). Generally, a very typical succession of resistant, opportunistic and sensitive species can be found along the gradient of pollution. In cases of severe pollution, the most impacted area may even be devoid of benthic life. In less severe cases, the faunas of the most polluted area are dominated by a small number of tolerant and/or opportunistic taxa, which may occur with high densities. Farther away from the source of pollution, these indicator taxa become less prominent, and are gradually replaced by a number of intermediate and sensitive species (Pearson, 1985; Pearson \& Rosenberg, 1978; Warwick, 1986; Weston, 1990).

In 1982, Locklin and Maddocks, 1982 first applied benthic foraminifera in a study on the impact of oil exploration activities on the sea floor. Recently, a monitoring method based on foraminiferal faunas has been tested in continental shelf and slope environments off Africa (Durrieu et al., 2006; Mojtahid et al., 2006; Jorissen et al., 2009). Benthic foraminifera have several characteristics which make them particularly useful for environmental monitoring. Foraminifera are present in all marine environments. In comparison to macrofauna, they have very high densities; from tens up to several thousands of individuals per $10 \mathrm{~cm}^{-3}$ (Murray, 2006). Because of these high standing stocks, large quantitative data sets can be produced on the basis of small sediment volumes. The diversity of the foraminiferal faunas alone is comparable to that of the entire macrofauna; up to a few hundred different species can be found at a single site (Murray, 2006). Because of this elevated bio-diversity, and the fact that they occupy a wide range of ecological niches (Murray, 2001), they potentially offer a large range of markers species. Finally, many foraminiferal species are protected by a calcareous shell, which after the death of the organism is preserved in the sediment and which will ultimately fossilize. In many cases, the study of the assemblage of dead foraminiferal shells at some $\mathrm{cm}$ depth in the sediment can give an idea about the composition of the foraminiferal faunas before the onset of oil exploitation activities. In this way, it is possible to reconstruct the natural faunas, which occupied the investigated area before the onset of oil production. This is very useful in cases where no baseline study has been performed, and constitutes an important advantage with respect to macrofauna.

Although their use as bio-indicators of oil production activities is new, foraminifera have been used for several decennia as bio-indicators of other types of anthropogenic impact, mainly in coastal areas (e.g. Watkins, 1961; Seiglie, 1968; 1971; Setty, 1976; Rao and Rao, 1979; Schafer, 1982; Setty and Nigam, 1984; Bhalla and Nigam, 1986; Nagy and Alve, 1987; Schafer et al., 1991; Alve, 1995; Coccioni, 2000; Bergin et al., 2006). In laboratory experiments, their response to various toxic substances has been tested, such as TBT (Gustafsson et al., 2000), heavy metals (de Nooijer et al., 2007; Le Cadre et al,. 2006; Saraswat et al., 2004) and oil (Ernst et al., 2006). These studies suggest that foraminifera are highly suitable for monitoring studies in open marine environments, but do not prove that 
foraminifera are as sensitive to pollution as macrofauna. At present, it is therefore not yet clear whether foraminifera have the same reliability as pollution indicators as the more commonly used macrofauna. To our knowledge, only a single study has compared the use of foraminifera and macrofauna as pollution indicators in an open marine environment. Mojtahid et al. (2008) studied the distribution of both groups around a sewage sludge disposal site at $80 \mathrm{~m}$ depth in the Firth of Clyde, off western Scotland. They found very comparable patterns for both groups, with poor macrofaunal and foraminiferal faunas at the disposal site, surrounded by an aureole of very rich opportunistic species. Still further away, these opportunistic taxa progressively disappear, and at about $3 \mathrm{~km}$ from the disposal site, faunas are comparable to those found at the reference station. In detail, some differences exist between the two groups; foraminifera appear to be more impacted at the disposal site, whereas at the outer edge of the studied area, foraminifera still indicate some environmental impact, whereas the macrofauna is already similar to that at the reference station.

Such a comparable study between foraminifera and macrofauna has never been made for the impact of oil drill muds. Therefore, in this paper, we will compare the results of two monitoring studies of the same drill mud disposal site off Congo, one based on the macrofauna, and one on benthic foraminifera. In this study, we will address several questions. First, we will investigate whether both groups respond in the same way to drill mud disposal, and whether their distributional patterns are organized similarly. Next, we will compare the spatial extent of environmental impact, as indicated by the two methods. This comparison will inform us about eventual differences in sensibility between the two groups. The results of our comparative study will reveal whether foraminifera are as adequate as bioindicators of drill mud disposal as macrofauna. The results will also inform us whether each of the two groups can be used independently, or whether there is a bonus in studying both groups.

\section{Materials and methods}

The study area is located off Congo, around the offshore oil drilling platform NKF2 in the N'Kossa field, at a water depth of about $180 \mathrm{~m}$. At this site, after the cessation of oil exploration activities in 1999, the macrofauna has been studied on the basis of 11 sediment samples taken in November 2000, 7 samples in March 2002 and 7 samples in April 2003. Unfortunately, the three sampling campaigns had only four samples in common (Table 1). In April 2003, sediment samples were also taken for foraminiferal analysis. Six sites of the 2002 macrofauna survey were revisited, at a distance of 70 to $2000 \mathrm{~m}$ of the disposal site, along a NNW/SSE transect. A seventh station, positioned at $450 \mathrm{~m} \mathrm{WNW}$ of the oil platform, was also sampled for foraminiferal studies. In this study, we will compare the more general data (standing stocks, biodiversity, biotic indices) of the foraminiferal faunas for April 2003 with the macrofaunal data of both the 2000, 2002 and 2003 sampling campaigns. For the comparison of individual taxa, we will limit our comparison of foraminifera and macrofauna to April 2003, when more or less the same samples were studied for both groups.

At each station, sediment samples have been taken with a Van Veen grab core with a surface area of $0.1 \mathrm{~m}^{2}$. Part of the upper $\mathrm{cm}$ of the sediment of each core has been used to determine sediment grain size, water concentration, total organic matter and organic carbon contents, total nitrogen and phosphorous, total hydrocarbons, and the concentrations of several heavy metals $(\mathrm{Cd}, \mathrm{Pb}, \mathrm{Hg}, \mathrm{Al}, \mathrm{Ba})$. For the study of the macrofauna, three Van Veen grab samples were collected, each with a surface area of $0.1 \mathrm{~m}$. Samples were taken until a depth of $15 \mathrm{~cm}$. After mixing in a barrel until a homogeneous mixture was obtained, samples were sieved over stainless steel sieves with $1 \mathrm{~mm}$ openings. The sieve residues $(>1 \mathrm{~mm})$ were washed with seawater, and packed into plastic bags, together with a solution of buffered formaldehyde and Rose Bengal. In the laboratory, a first inventory allowed to determine all organisms by phylum. After a more detailed study, most organisms could be determined at a species or generic level. The faunal density of each taxon at each station, the species richness and the total faunal density (number of individuals per $\mathrm{m}^{2}$ ) were 
calculated. In order to facilitate the interpretation of the macrofaunal data, the taxa have been tentatively divided into four trophic groups, defined by Word (1979), with different feeding behavior:

Group 1 is dominated by suspension feeders, feeding in the water column,

Group 2 contains taxa that feed on suspended material or detritus at the sediment-water interface

Group 3 is dominated by surface detritus feeders, foraging in the oxic upper part of the sediment, and

Group 4 groups all taxa which feed on detritus in deeper sediment layers, often in dysaerobic ecosystems.

In order to give an overall assessment of the state of the environment, for each station, the Infaunal Trophic Index (ITI, Word, 1979) was calculated, using the expression:

$$
I T=100-\left[\frac{33,33(0 n 1+1 n 2+2 n 3+3 n 4)}{n 1+n 2+n 3+n 4}\right]
$$

where $n 1, n 2, n 3, n 4$ represent the densities of the four trophic groups described previously. It is thought that the ITI index gives an adequate description of the response of a benthic community to organic matter enrichment. It has been used with success in many ecological studies (e.g. Word, 1979; 1980, Maurer et al., 1999, Giménez Casalduero, 1999, Grall and Hily, 2003). Bascom et al. (1979) suggested to distinguish three intervals on the basis of the IT index, to define various degrees of environmental disturbance. In cases where the ITI index is above 60, the fauna is usually considered as normal, and the environment is supposed not to be impacted by organic enrichment. When the ITI index is between 30 and 60 , the faunal assemblage is supposed to be subject to organic matter enrichment, and the environment is considered as moderately impacted. Finally, when the ITI index is lower than 30 , the faunal assemblage is subject to a high degree of organic matter enrichment, and the environment is considered to be severely impacted.

For the study of the foraminiferal faunas, Van Veen grab cores were subsampled with a Plexiglas core with an inner diameter of $4 \mathrm{~cm}$ (a surface area of $12.56 \mathrm{~cm}^{2}$ ). The cores were sliced into $0.5 \mathrm{~cm}$ intervals down to $1 \mathrm{~cm}$ and then in $1 \mathrm{~cm}$ intervals down to $7 \mathrm{~cm}$ depth. Samples were packed in sealed plastic bags to which 95\% Ethanol with $1 \mathrm{~g} / \mathrm{L}$ Rose Bengal was added. In the laboratory, samples were sieved through meshes with $>63$ and $>150 \mu \mathrm{m}$ openings. For the fraction larger than $150 \mu \mathrm{m}$, living foraminifera were sampled down to $3 \mathrm{~cm}$ depth, whereas for the 63-150 $\mu \mathrm{m}$ fraction, we studied the uppermost $2 \mathrm{~cm}$. For the $>150 \mu \mathrm{m}$ fraction of the surface level $(0-0.5 \mathrm{~cm})$ and of the level $2-3 \mathrm{~cm}$, foraminifera have been sorted out wet (in $50 \%$ ethanol) without preliminary treatment. In order to accelerate the picking, which was very time-consuming because of the large quantities of sediment grains, for the $0.5-1 \mathrm{~cm}$ and $1-2 \mathrm{~cm}$, as well as for all samples of the $63-150 \mu \mathrm{m}$ fraction, foraminifera were concentrated by density separation using trichloroethylene $(D=1.46)$. This method concentrates the living foraminifera in the floated part. A careful check of the deposited sediment revealed an absence of live individuals, showing the efficiency of the method. All selected foraminifera were determined using common taxonomic reference studies. In order to give an overall appreciation to each of the samples, and to enable comparison with the IT index based on macrofauna, we determinated the values of a foraminiferal index of environmental impact (FIEI), proposed by Mojtahid et al., 2006:

$$
E I E I=\frac{\left(n_{r}+n_{\Omega}\right)}{N_{T Q T}} * 100
$$

where $n_{r}$ is the total quantity of pollution-resistant taxa, $n_{0}$ is the number of individuals of opportunistic taxa and $\mathrm{N}_{\text {TOт }}$ is the total number of individuals in the foraminiferal assemblage. These opportunistic and tolerant taxa were recognized on the basis of the spatial patterns in 
the study area, and a comparison of live and dead foraminifera found in slightly deeper sediment layers, which are thought to represent pre-impacted conditions. See Mojtahid et al. (2006) for more detailed information.

\section{Results}

\section{A. Geochemical data}

The curves describing the hydrocarbon concentrations around the disposal site in 2000, 2002 and 2003 (Fig. 2) have all the same tendency. For all three years, there is a conspicuous maximum at station $6,70 \mathrm{~m} \mathrm{~W}$ of the disposal site. In 2000, the maximum hydrocarbon concentration at this station was about $170 \mathrm{~g} / \mathrm{kg}$ dry weight, in 2002 and 2003 it was somewhat lower, with 65 and $110 \mathrm{~g} / \mathrm{kg}$, respectively (Dalmazzone et al., 2004; Durrieu \& Bouzet, 2004). Away from the disposal site, hydrocarbon concentrations rapidly decrease, until only trace amounts are found at $500 \mathrm{~m}$ distance.

Also for Barium, the highest value is observed at $70 \mathrm{~m} \mathrm{~W}$ from the disposal site. In 2000 and 2002 this maximum concentration was about $150 \mathrm{~g} / \mathrm{kg}$ dry weight, and in 2003 about $95 \mathrm{~g} / \mathrm{kg}$ dry weight (Dalmazzone et al., 2004; Durrieu \& Bouzet, 2004). The values show a rapid decrease until $500 \mathrm{~m}$ where they become insignificant.

\section{B. Macrofauna: density and diversity patterns, trophic infaunal index}

The results of the macrofaunal surveys of 2000, 2002 and 2003 macrofauna surveys show very comparable general tendencies, although there are some minor differences. In the next description of faunal data, we will therefore present the three sampling campaigns together, in the same graphs.

In 2003, the faunal density (an average of three samples studied for each station) varies from 100 to 250 individuals per $\mathrm{m}^{2}$ from 2000 to $500 \mathrm{~m}$ from the discharge point (Fig. 3). From 500 $\mathrm{m}$ towards the platform, the faunal density shows a very strong increase until a maximum value of 8600 individuals per $\mathrm{m}^{2}$ is reached at station 13, $100 \mathrm{~m} \mathrm{~S}$ of the platform. At station $6,70 \mathrm{~m} \mathrm{~W}$ of the disposal site, the density is still very strong with 5000 individuals per $\mathrm{m}^{2}$. In 2002 , the faunal density shows the same pattern with values of about 500 individuals per $\mathrm{m}^{2}$ from 2000 to $500 \mathrm{~m}$ from the disposal site. From $500 \mathrm{~m}$ towards the disposal site, the faunal density shows a strong and progressive increase, until a maximum value of 6800 individuals per $\mathrm{m}^{2}$ is found $100 \mathrm{~m} \mathrm{~S}$ of the platform. At station $6,70 \mathrm{~m} \mathrm{~W}$ of the disposal site, the density is somewhat lower, with 2300 individuals per $\mathrm{m}^{2}$. Also the data of the 2000 survey are fairly similar. At both sides (NNW ads SSE) of the platform, background values of about 300 individuals per $\mathrm{m}^{2}$ are found further than $500 \mathrm{~m}$ from the platform. However, in 2000 , the abundance maximum, of about 3000 individuals per $\mathrm{m}^{2}$, found at station $5,175 \mathrm{~m} \mathrm{SSE}$ of the platform, is less prominent than in 2003 and 2002.

In 2003, species richness shows values between 20 and 40 from $2000 \mathrm{~m}$ to $250 \mathrm{~m}$ from the discharge point (Fig. 4.). Species richness decreases closer to the platform until a minimum of 20 species is found $70 \mathrm{~m} \mathrm{~W}$ of the disposal site. In 2002, species richness was generally higher, but a similar pattern is visible. The species number varies from 45 to 60 between $2000 \mathrm{~m}$ and $250 \mathrm{~m}$ from the disposal site. When approaching the disposal site, the species richness rapidly decreases until a minimum of 15 species $70 \mathrm{~m}$ west of the discharge point. In 2000 , the species richness follows the same pattern, but values are generally lower. At both sites of the platform, about 40 species are found at $2 \mathrm{~km}$ distance. SSW of the platform, there is a gradual decrease towards the disposal site. NNW of the platform, on the contrary, species richness remains elevated until station 8 , at $500 \mathrm{~m}$, where a maximum of 45 species is observed. Closer to the disposal site, species richness decreases rapidly. A minimal species richness, of only 15, is found at station 6 .

The ITI index (Infaunal Trophic Index, Word, 1979) shows a very similar overall pattern for 2000, 2002 and 2003. In 2003, it varies from 55\% to 60\% between $2000 \mathrm{~m}$ and $500 \mathrm{~m}$ from 
the discharge site (Fig. 5). From $500 \mathrm{~m}$ towards the platform, values decrease until a minimum of $5 \%$ at about $70 \mathrm{~m}$ from the disposal point (station 6). At S17, about $450 \mathrm{~m} \mathrm{WNW}$ of the platform, the ITI index is about 35\%. In 2002, the ITI is about $60 \%$ from $2000 \mathrm{~m}$ to 500

$\mathrm{m}$ of the discharge point. From 500 $\mathrm{m}$ to the disposal site, it rapidly decreases to a minimum value of only $3 \%$ at $70 \mathrm{~m}$ from NFK2. In 2000, minimum values, of $7 \%$ and $8 \%$ where observed $70 \mathrm{~m} \mathrm{~W}$ and $175 \mathrm{~m} \mathrm{SSE}$, respectively. Further SSE of the disposal site, the values for 2000 are almost identical to those of 2002. To the NNW, the ITI varied between $60 \%$ and $70 \%$ at distances larger than $150 \mathrm{~m}$ from the disposal site.

\section{Foraminifera: density and diversity patterns, foraminiferal index}

The foraminiferal faunas were only sampled in 2003. A detailed description of the data is given in Mojtahid et al., 2006. In figure 6, the foraminiferal data are presented separately for the two investigated size fractions: all data for the $>150 \mu \mathrm{m}$ fraction are based on an inventory of the topmost $3 \mathrm{~cm}$, whereas the data for the $63-150 \mu \mathrm{m}$ fraction pertain to the topmost $2 \mathrm{~cm}$. Between $2000 \mathrm{~m}$ and $500 \mathrm{~m}$ from the disposal point the foraminiferal densities show values of 5 to 30 individuals per $10 \mathrm{~cm}^{2}$ for the $>150 \mu \mathrm{m}$ fraction and of 25 to 40 individuals per $10 \mathrm{~cm}^{2}$ for the $63-150 \mu \mathrm{m}$ fraction. From $500 \mathrm{~m}$ to the disposal point, densities increase in both size fractions. A maximum is observed at station 4 , at a distance of $230 \mathrm{~m}$, where 170 and 250 individuals per $10 \mathrm{~cm}^{2}$ are found in the $>150 \mu \mathrm{m}$ and $63-150 \mu \mathrm{m}$ fraction, respectively. Still closer to the platform, densities decrease, until values of 15 and 60 individuals per $10 \mathrm{~cm}^{2}$ are found at station 6 , at $70 \mathrm{~m}$ distance. Also at station $17,450 \mathrm{~m}$ NNW of the discharge sites, the faunas are very poor, with 10 and 20 individuals per $10 \mathrm{~cm}^{2}$ in the $>150 \mu \mathrm{m}$ and $63-150 \mu \mathrm{m}$ fraction, respectively.

The species numbers show a rather irregular pattern (Fig. 7). SSE of the disposal site, the species number increases from 5 for each of the two fractions at $2000 \mathrm{~m}$, to a maximum of 30 for the fraction $>150 \mu \mathrm{m}$ and 25 for the fraction $63-150 \mu \mathrm{m}$ at $230 \mathrm{~m}$. However, this trend is interrupted by minimum values at station 3 , where the foraminiferal fauna is very poor. At station $17,500 \mathrm{~m}$ NNW of the platform, the species number is only 9 for the fraction $>150 \mu \mathrm{m}$ and 1 for the fraction 63-150 $\mu \mathrm{m}$. Also at the two stations closest to the disposal site, the species numbers are fairly low ( 9 and 12 for the fraction $>150 \mu \mathrm{m}$ and 5 and 16 for the fraction 63-150 $\mu \mathrm{m}$, at stations 6 and 13, respectively).

The FIEI (foraminiferal index of environmental impact) is exclusively based on an inventory of the $>150 \mu \mathrm{m}$ size fraction. In Figure 8, the FIEl shows increasing values from a minimum of $15 \%$ at $2000 \mathrm{~m}$ distance from the disposal point to a maximum of $85 \%$ at $100 \mathrm{~m}$ south of the platform. To the NNW, the FIEI decreases again, until $50 \%$ at $450 \mathrm{~m}$.

\section{Macrofaunal and foraminiferal indicator species}

In this chapter, we will compare macrofaunal and foraminiferal taxa with distributional patterns suggesting a particularly strong response to the disturbance brought about by the oil activities. Since we have only foraminiferal data for 2003 , we will focuss our comparison of macrofaunal and foraminiferal data on the 2003 data set.

Because of their high apparent sensitivity or tolerance to the environmental perturbations caused by oil mud discharges, we have selected eighteen macrofaunal indicator species. These species consists of 15 annelid polychaetes, two bivalves and one nemertean worm. Fig. 11 shows the average densities (for the three replicates cores)of these 18 macrofaunal indicator taxa along the sampling transect.

Sigambra sp. and Capitella capitata strongly dominate the faunas around the disposal site. Sigambra sp. reaches maximal densities of about 4500 individuals per $\mathrm{m}^{2}$ at station $6(70 \mathrm{~m}$ $\mathrm{W}$ of the platform). Slightly further away from the disposal site, it is followed by Capitella capitata which attains a maximum density, of about 3500 individuals per $\mathrm{m}^{2}$, at station 13 , $100 \mathrm{~m} \mathrm{~S}$ of the disposal site, and 600 individuals per $\mathrm{m}^{2}$ at station 4, 250 SSE of the platform. The densities of both taxa decrease dramatically further away from the disposal site, until only trace amounts are found at $500 \mathrm{~m}$. In figure 9 the 2003 data for these 2 taxa are 
compared with the 2000 and 2002 data. Although the absolute densities differ, the patterns are very similar in these three years.

Four other taxa, Ampharetidae Genus A, Anodontia edentula, Loripes cf. L. contrarius and Paramphinome cf. tryonix are all found with high densities at stations 13 and 4, $100 \mathrm{~m}$ and $230 \mathrm{~m}$ SSE of the disposal site, respectively. The first three taxa all have a clear density maximum, of 500-600 individuals per $\mathrm{m}^{2}$, at station 13. At station 4 , the densities of these taxa are significantly lower, about 400 ind $/ \mathrm{m}^{2}$ for $A$. edentula and $150-200$ ind $/ \mathrm{m}^{2}$ for Ampharetidae Genus A and L. cf. contraries. Paramphinome cf. tryonix shows very similar densities, but with a slightly different pattern. It is present with about $500 \mathrm{ind} / \mathrm{m}^{2}$ at station 13 , but reaches a maximal density of about $650 \mathrm{ind} / \mathrm{m}^{2}$ at station $4,230 \mathrm{~m} \mathrm{SSE}$ of the platform. Further away from the discharge point, the densities of these 4 taxa decrease rapidly until they are close to zero at station 3, 470 SSE of the platform.

Glycera sp.1, Prionospio cf. multibranchiata and Spiophanes sp. are less frequent taxa, that all reach maximum densities at station $4,230 \mathrm{~m} \mathrm{~S}$ of distance from the platform. The maximum values for these three species are 70, 140 and 25 individuals per $\mathrm{m}^{2}$, respectively. At station 13, $100 \mathrm{~m}$ S of the platform, Glycera sp.1 (120 individuals per $\mathrm{m}^{2}$ ) and Spiophanes sp. (20 individuals per $\mathrm{m}^{2}$ ) have still a fairly high density, whereas Prionospio cf. multibranchiata is almost absent.. All three species show a rapid density decrease toward station 3, $470 \mathrm{~m}$ SSE and station 6, $60 \mathrm{~m} \mathrm{~W}$ from the discharge point.

Spiochaetopterus sp., Monticellina dorsobranchialis and Marphysa sp., which occur with lower densities, have a very similar pattern. These three taxa show all a maximum at station $3,470 \mathrm{~m}$ SSE from the platform, of 15 to 25 individuals per $\mathrm{m}^{2}$. They are all absent at stations 6, 13 and 4, less than $250 \mathrm{~m}$ from the disposal site.. To the NNW, they reappear at station 17, at $500 \mathrm{~m}$ distance, with densities of about 10 individuals per $\mathrm{m}^{2}$.

Aphelochaeta sp., Anobothrus gracilis and Nemertien sp.1 all reach maximum densities, of 10 to 40 individuals per $\mathrm{m}^{2}$ at station 16, $730 \mathrm{~m}$ SSE of NFK2 and station 17, $500 \mathrm{~m}$ NNW of the platform. Further away from the platform, the densities decrease. At station 2, $2000 \mathrm{~m}$ SSE of the platform, only Anobothrus gracilis is found. Except for a limited appearance of Aphelochaeta sp. at station 4, these taxa are absent at all stations close to the disposal point.

Aricidea assimilis, Sternaspsis scutata and Cossura cf. costata all reach a maximum density of about 10 individuals per $\mathrm{m}^{2}$ ) at station 2, $2000 \mathrm{~m} \mathrm{SSE}$ of the disposal site. They are all rare closer to the platform, but Aricidea assimilis re-appears at station 17, $500 \mathrm{NNW}$ of the disposal site.

A very similar approach has been followed for foraminifera, for which 13 indicator taxa have been selected.

In the $>150 \mu \mathrm{m}$ fraction, Bulimina marginata, Bulimina costata, Trifarina bradyi and Uvigerina peregrina all have a maximum density at station $13,100 \mathrm{~m}$ SSE of the disposal site. Maximum densities vary from 20 ind $/ 10 \mathrm{~cm}^{2}$ for $B$. marginata to 10 to 15 ind $/ 10 \mathrm{~cm}^{2}$ for the other three species. Their densities progressively decrease towards the sites farther away from the platform, although $U$. peregrina is still present in affair numbers at station 16 .

Bulimina aculeata and Textularia sagitula attain a maximum density at station 4, of 25 and 7 individuals per $\mathrm{m}^{2}$, respectively. Both taxa are also present at station $13,100 \mathrm{~m}$ SSE of the platform. With increasing distance, their densities rapidly decrease until minimum amounts are found at station 3 (250 m SSE).

Also Amphicoryna scalaris and Eggerella sp. 1 both have a maximum density, of about 35 ind $/ 10 \mathrm{~cm}^{2}$, at station $4(230 \mathrm{~m} \mathrm{SSW})$. Rather surprisingly, this is the only station where these taxa appear with significant numbers. At all other stations, they are nearly absent.

In the 63-150 $\mu \mathrm{m}$ fraction, Valvulineria bradyana and Bolivina dilatata present a maximum of about 6 ind $/ 10 \mathrm{~cm}^{2}$ at station 13,100m SSE. Their densities rapidly decrease in all directions. Bulimina marginata and Gyroidina sp.1 show maximum values at stations 4 and $13(230 \mathrm{~m} \mathrm{~S}$ and $100 \mathrm{~m} \mathrm{~S}$ ), of about 35 and $25 \mathrm{ind} / 10 \mathrm{~cm}^{2}$, respectively. Both species are present with about $10 \mathrm{ind} / 10 \mathrm{~cm}^{2}$ at station $6(70 \mathrm{~m} \mathrm{~W})$, and decrease very rapidly towards all more 
distanced stations. Finally, Bolivina striatula, Bolivina semunida and Bulimina aculeata show a conspicuous maximum at station $4(230 \mathrm{~m} \mathrm{~S})$, with about 70,25 and $20 \mathrm{ind} / 10 \mathrm{~cm}^{2}$, respectively. At all other stations, their densities are minimal.

\section{Discussion}

In the next pages, we will compare the macrofaunal and foraminiferal response to the input of drill cuttings, and investigate whether foraminifera have the same potential to be used as bio-indicators of oil exploration and exploitation activities as the much more commonly used macrofauna, and whether there is a bonus in using both groups together.

In our study area, the benthic environment is impacted by the disposal of oily drill cuttings. The spatial distribution of hydrocarbon concentrations suggests that environmental perturbation is maximal at station $6,70 \mathrm{~m} \mathrm{~W}$ of the platform, where a maximum hydrocarbon concentration is observed, of about $160 \mathrm{~g}$ per kilo. Barium concentrations show the presence of drill cuttings until S4, $230 \mathrm{~m} \mathrm{~S}$. At about $500 \mathrm{~m}$ from the platform, both hydrocarbons and Ba-contents fall to zero, suggesting the absence of drill cuttings. The supply of such an important quantity of hydrocarbon will cause a strongly increased oxygen demand at the sediment-water interface and in the uppermost sediment layer, needed for the aerobic degradation of the oil components. Unfortunately, no oxygen measurements were performed during the sampling surveys. Nevertheless, the benthic environment should be characterized by strongly hypoxic conditions. Ultimately, hydrocarbon input will cause a strong eutrophication of the benthic ecosystem, comparable to the eutrophication phenomena observed in areas impacted by the disposal of organic-rich waste (e.g. Parr et al., 2007; Schaanning et al., 2008; Venturini et al., 2008). Since a low toxicity oily drill mud has been applied, the probability that the benthic faunas heavily suffer from the toxic components of the hydrocarbons is relatively limited (Dalmazzone et al., 2004; Neff, 2005). The oily drill cuttings also contain large quantities of barium, which is relatively inert (and not toxic) in the marine environment, but can be used as a tracer of the dispersal of drill cuttings on the sea floor (Chow, 1976; Zemel, 1995; Kennicutt et al., 2006).

\section{A. Macrofauna}

On the basis of the community structure (total density, species richness and trophic index) of the macrofauna, four groups of stations can be recognized along our sampling transect:

1) At reference stations 2 et 10 , total faunal density is low $\left(<1000\right.$ individuals per $\mathrm{m}^{2}$, fig. 3$)$, whereas species richness is high (> 30, fig. 4). The high trophic index (>60\%, fig. 5) suggests that environmental impact is minimal at these stations. In 2003, the polychaete worms Aricidea assimilis, Sternaspsis scutata and Cossura cf. costata were dominant faunal elements. These species all have a large body size typical of animals with a slow turnover rate, living in non stressed and well oxygenated environments.

2) Stations 3, 16 (500 and $730 \mathrm{~m} \mathrm{SSE}$ ), 9, 17 and 8 (500 to $300 \mathrm{~m} \mathrm{NNW)} \mathrm{are} \mathrm{very} \mathrm{similar.}$ Faunal density is still low ( $<1000$ individuals per $\mathrm{m}^{2}$, fig. 3 ), species richness high $(>30$, fig. 4), and the trophic index is above 60 (fig. 5). However, in 2003, there were some differences in faunal composition. A.assimilis, S. scutata and C. cf. costata had a lower density than at station 2, whereas at stations 16 and 17, Aphelochaeta sp., Anobothrus gracilis and Nemertien sp.1 showed rather elevated densities. At station 3, Spiochaetopterus sp., Monticellina dorsobranchialis and Marphysa sp. showed higher densities than at reference station 2. Although barium and hydrocarbons concentrations are close to zero at these stations, and the nine taxa most resistant to environmental disturbance (Fig. 10A-C) were almost completely absent, the slightly different faunal composition, especially at stations 3 and 16 , suggests that the environmental conditions are somewhat different than at the reference stations.

The third group consists of stations 4 and 7, at $230 \mathrm{~m} \mathrm{SSE}$ and $150 \mathrm{~m} \mathrm{WNW}$, respectively. Here, the faunal density shows a strong increase (fig. 3), but species diversity is still fairly 
elevated. In 2002, species richness was even maximal at station 4 (fig. 4). The trophic index shows intermediate values (20-30\%) at station 4 , but is still very high at station 7 , which was only sampled in 2000. At both stations, elevated Barium contents show the presence of drill muds. However, slightly elevated hydrocarbon vales were only observed in 2000 , at station 4. It appears that the faunas at these two stations respond to a moderate environmental impact due to oil drilling activities. Unfortunately, station 17 was not sampled in 2003. In that year, the fauna of station 4 was strongly dominated by Capitella capitata and Sigambra sp., whereas Paramphinome cf. tryonixa and Anodontia edentula were very frequent. The taxa $P$. cf. tryonixa, Prionospio cf. multibranchiata, Glycera sp.1, and Spiophanes sp. all attained a maximum at this station. The distributional patterns of these taxa strongly suggest an opportunistic response to an increased organic matter availability. The taxa dominating the second group of stations are still present, but in much lower quantities.

The fourth and last group contains stations 5, 13 and 6, at $175 \mathrm{~m} \mathrm{SSE}, 100 \mathrm{~m} \mathrm{~S}$, and $70 \mathrm{~m} \mathrm{~W}$ of the discharge point, respectively. Here, faunal density attains a maximum, whereas species richness is minimal (figs 3-4). This decreased species richness is a result of the almost total disappearance of all sensitive taxa. In all years, the trophic index was below $20 \%$. At all three stations, hydrocarbon and barium concentrations are very high. All these data point to a severe impact of the oil drilling activities on the benthic macrofauna.

In 2003 , the faunas of these heavily impacted stations were strongly dominated by Sigambra sp. and Capitella capitata, two polychaete worms commonly found in sediments characterized by intense organic enrichment (Warwick, 1986; Weston, 1990). Especially the species Capitella capitata shows in many studies a marked proliferation in the immediate vicinity of the disposal point of organic waste, followed by strongly decreasing densities with increasing distance from the point source (e.g. Grassle and Grassle, 1974; Rosenberg, 1976, McCall, 1977; Pearson and Rosenberg, 1978; Kikuchi, 1979; Gray, 1981 and Tsutsumi and Kikuchi, 1984). Also the genus Sigambra is known to be an opportunistic species considered like indicators of organic enrichment (Mackie et al, 1993; Brooks et al, 2004).

In 2003, station 5 was unfortunately not sampled. A remarkable difference in faunal composition can be noticed between stations 13 and 6 . At station $6(70 \mathrm{~m} \mathrm{~W})$, the fauna was totally dominated by Sigambra sp., although Capitella capitata is present with a low density. At station $13(100 \mathrm{~m} \mathrm{~S})$, the fauna is strongly dominated by Capitella capitata and Sigambra sp., which were present in about equal quantities. However, also Ampharetidae Genus A, Anodontia edentula, Loripes cf. L. contraries and Paramphinome cf. tryonix were present in considerable amounts. At station 6, the latter 4 taxa were almost absent. These differences suggest that in 2003, station 6 was more severely impacted than station 13 . This corresponds to the maximum hydrocarbon concentrations observed at this station in 2003. A similar situation was observed in 2002, when the fauna at station 6 was heavily dominated by Sigambra sp., whereas this species occurred together with C. capitata at station 13 (Fig. 9). In 2000 , both species occur with elevated densities at station 6 , suggesting that this station was slightly less impacted in this year.

The macrofaunal distribution described above shows a very typical pattern, which has previously been described around other point sources of organic matter input (e.g. Mackay et al., 1972; Pearson \& Rosenberg, 1978). The changes in faunal density, biodiversity and composition are caused by the fact that the density of each taxon changes in response to the level of environmental stress. The more sensitive species progressively decrease in density when the sediment quality deteriorates, and are replaced by more tolerant taxa, which are rare or absent at the non impacted sites (e.g. Chandler, 1970; Washington, 1984; Hellawell, 1986). In our study, in the vicinity of the disposal site, where environmental impact at the sediment-water interface is maximal, the species richness is minimal, but the total faunal density is very high. Most of the sensitive species have disappeared and only the most resistant, often very opportunistic taxa are capable to survive and proliferate. With increasing distance from the disposal site, environmental impact appears to diminish (as indicated by the decreasing hydrocarbon concentrations), and biodiversity increases due to the 
appearance of more sensitive taxa. Since organic matter becomes less abundant, the proliferation of the opportunistic/resistant species becomes less prominent, resulting in an overall decrease of faunal density. Station 4, at $250 \mathrm{~m} \mathrm{~S}$ of the discharge point, shows a combination of increased faunal density and maximal species richness, typical of an ecotone. On the one hand, the opportunistic response to increased organic matter availability leads to a high faunal density. On the other hand, conditions are not stressful enough to cause to the disappearance of more sensitive taxa; the co-existence of opportunistic/tolerant and sensitive taxa at this station explains the maximum species richness. Further than $250 \mathrm{~m}$ from the disposal site, conditions become progressively similar to those found at the reference station. This is reflected by the strongly changing community structure, with an almost total disappearance of the tolerant/opportunistic species, and a return to minimal faunal densities and elevated species richness.

\section{B. Foraminifera}

The distributional pattern of the foraminiferal faunas has been described in detail by Mojtahid et al. (2007). As we will explain in the following paragraphs, the foraminiferal patterns show some similarity to those of the macrofauna, but display also some remarkable differences.

For the foraminiferal faunas, the overall faunal characteristics allow us to distinguish 4 groups of stations. However, it should be kept in mind that the 7 stations were only studied once, in 2003.

The reference station 2, $2000 \mathrm{~m} \mathrm{SSW}$ of the disposal point, shows a low foraminiferal density, and a low species richness. The very low FIEl (Foraminiferal Index of Environmental Impact), of about 15 , is indicative of a low relative proportion of taxa resistant to environmental impact, and thus, the presence of a fauna typical of natural, non-impacted conditions. Mojtahid et al. (2007) suggested that the low faunal densities in this area could be due to the presence of strong bottom currents, causing a relatively coarse, silty to fine sandy substrate, less favorable for mud-dwelling foraminifera.

A second group contains stations 16, 3 and 17, between 450 and $730 \mathrm{~m}$ from the disposal site. Also at these stations, faunal density and diversity are low. However, the FIEl, which is based on the cumulative percentage of opportunistic and stress-tolerant taxa, increases to values between 40 and 55 . This suggests that within the rather poor faunas, the relative percentage of stress-resistant and opportunistic taxa has increased in response to a low degree of environmental stress. Most prominent is the frequency increase of $U$. peregrina (Fig. 11) and B. dilatata (Fig. 12) at station 16. These species have often been described as markers of increased food availability in marine benthic ecosystems. (e.g. Lutze and Coulbourn, 1984; Lutze, 1986; Barmawidjaja et al., 1995; Mackensen et al., 1995;Kuhnt et al., 1999; De Rijk et al., 2000; Huang et al., 2002) In case the first signs of ecosystem eutrophication are indeed found at station 16 (as suggested by the increased FIEI), and if this phenomenon intensifies towards the disposal site, the very low faunal density at station 3 is surprising. It contrasts with the relatively high FIEl found at this station. Mojtahid et al. (2007) therefore suggested that the low faunal density may be due to inadequate sampling of the sediment surface. If true, this would underline the necessity to sample undisturbed sediment surfaces for the study of the foraminiferal faunas.

The third group contains stations 4 and 13, $230 \mathrm{~m}$ SSW and $100 \mathrm{~m} \mathrm{~S}$ of the disposal site, respectively. At both stations, faunal density and diversity are very high, although a maximum is reached at station 4 , and values are lower at station 13 . The FIEI attains values above 60 , suggesting a strong environmental impact of oily drill mud disposal. In detail, a faunal succession can be observed from station 4 to station 13. Bolivina striatula, Bulimina aculeata, Amphicoryna scalaris and Eggerella sp. 1 are very rich at station 4, and are found in much lower numbers at station 13. Bulimina marginata and Gyroidina sp. 1 occur with comparable densities at both stations, whereas Bulimina costata, Uvigerina peregrina, Valvulineria bradyana and Bolivina dilatata are much richer at station 13 than at station 4 . In our opinion, we see here a succession of more opportunistic taxa which dominate at station 4 to more stress-tolerant, and less opportunistic, taxa at station 13. This idea is collaborated by 
the fact that the taxa with a maximum density at station 13 have lower standing stocks than those with a maximum at station 4. It is especially remarkable that both Amphicoryna scalaris and Eggerella sp. are dominant faunal elements at station 4, but are almost absent at station 13. As is suggested by the FIEI, environmental stress appears to be higher at station 13 $(\mathrm{FIEI}=85)$ than at station $4(\mathrm{FIEI}=65)$. It appears that these two taxa are still capable to profit from the eutrophicated conditions at station 4 , but that environmental stress has risen beyond their tolerance levels at station 13.

The fourth group contains only station $6,70 \mathrm{~m} \mathrm{~W}$ of the disposal site. Here, the foraminiferal density is more or less similar to the reference station 2 , but much lower than at stations 4 and 13. The FIEI index of about 70 is still very high. Bulimina marginata, Bulimina costata, Bulimina aculeata and Bolivina striatula are dominant faunal elements. It appears that most opportunistic taxa suffer too much from adverse environmental conditions to attain high standing stocks.

\section{Comparison Macrofauna/Foraminifera}

Although the overall patterns of the macrofaunal and foraminiferal faunas show a fair similarity, a more profound analysis shows some important differences. These differences are already present in the main parameters, density and diversity:

In terms of standing stocks, both macrofauna and foraminifera show a perspicuous maximum at some distance from the disposal site, and decreasing densities both towards the disposal site and to sites farther away. For macrofauna, maximal densities are found at station 13, $100 \mathrm{~m}$ south of the disposal site, whereas for foraminifera, maximal density is found at station $4,250 \mathrm{~m}$ south.

For macrofauna, the maximal density at station 13 is about 20 times higher than at the reference station. For foraminifera the faunas at station 4 show a 15 -fold increase in comparison to those of the reference station. In the $63-150 \mu \mathrm{m}$ fraction, there is a tenfold increase, whereas in the $>150 \mu \mathrm{m}$ fraction, the faunal density is about 30 times higher at station 4 than at station 2.

For the macrofauna, the faunal density at station 6 , closest to the disposal site, is still an order of magnitude higher than at the reference station, whereas for foraminifera, standing stocks are very low, and comparable to those of the reference station.

Diversity is for both groups highest at station 4, which appears to be an ecotone, with a mixture of species with very different ecological strategies.

For the macrofauna, there is a tendency of an inverse correlation between faunal density and species number. For foraminifera, on the contrary, these two parameters show a clear positive correlation. This difference can be explained in several ways. Many macrofauna species are very sensitive to stressed conditions, which can explain their absence at the disposal site. On the contrary, such sensitive species may not exist in foraminifera, which can occur at all stations. Alternatively, due to their small size, and in the hypothetical presence of strong bottom currents, foraminifera can easily be transported. Such a transport mechanism could explain why low amounts of sensitive species can even be found at severely impacted sites. And finally, one may wonder whether this correlation is not due to the low foraminiferal numbers in some of the samples, which suggest that a larger sediment volume should have been sampled to obtain a more complete picture of the biodiversity of the foraminiferal faunas.

These distributional differences between macrofauna and foraminifera suggest that these two groups have not exactly the same response to environmental perturbation related to drill mud disposal. Firstly, at the disposal site, foraminifera appear to be more heavily impacted than macrofauna. Their low densities suggest that we are close to azoic conditions, which have been described for severely impacted sites (e.g. Schafer, 1970; Alve, 1995; Burone et al., 2006, Mojtahid et al., 2008). For macrofauna, the elevated densities indicate that we are still far away from such critical conditions. Secondly, this higher foraminiferal sensitivity is 
confirmed by the localisation of the peak of opportunists. This is positioned $100 \mathrm{~m}$ south of the disposal site for macrofauna, and $250 \mathrm{~m}$ south for foraminifera.

Also at a species level, some perspicuous differences between macrofauna and foraminifera can be noticed. First, in the macrofauna, there is a number of species which show a maximum frequency at the reference station(s), and which rapidly disappear towards sites closer to the drilling platform. Such taxa are usually considered as sensitive to pollution. Rather surprisingly, none of the dominant foraminiferal taxa shows such a distributional pattern. Although we can not exclude that some low frequent taxa are sensitive to ecosystem perturbation, the cumulative density of these taxa is always very low. Next, in the macrofauna, there is a succession of first and second order opportunistic species, characterised by strong increases of their standing stocks, from station 16 (730 m SSE) to station 6. Towards the disposal site, the absolute densities of these opportunistic taxa show a strong decrease. Even at the most impacted stations 6 and 13, where the faunal density is very low, the two dominant taxa show very higher densities, indicative of their opportunistic life strategy. For foraminifera, a similar succession of opportunistic species is observed, but after frequency maxima observed at stations 4 and 13, at station 6 the most resistant taxa are present in much lower densities, indicating that they no longer have an opportunistic response to the stressed conditions.

It appears therefore that macrofauna and foraminifera have a very similar response, with an area with strongly enriched opportunistic faunas at some distance, and a subsequent decrease to azoic conditions at sites of maximum impact, but that this succession is positioned at larger distance from the disposal site in the case of foraminifera than in the case of macrofauna (Figs. 3 and 6).

In view of the differences between these two groups, quantitative methods, using a biotic index, can not be constructed in exactly the same way. For macrofauna, we use here the infaunal trophic index (ITI, Word, 1979), which has been used successfully in many earlier studies (e.g., Wildish, 1984; Gaston, 1987; Gaston and Nasci, 1988; Karakassis and Eleftheriou, 1997; Gaston et al., 1998) and is based on the feeding strategy of the species. The level of environmental impact is indicated by the response of differential response of the various trophic groups to the changing environmental conditions. In comparison to other biotic indices, such as AMBI (Borja et al., 2005), which use rather subjective ecological characterizations of the various species (sensitive, intermediate, $1^{\text {st }}$ and $2^{\text {nd }}$ order opportunist, etc.), the advantage of the ITI is that for most species, the feeding strategy is well known, and has been observed objectively (Grall \& Hily, 2003).

For foraminifera, such an approach is not possible. The large majority of our taxa are shallow infaunal deposit feeders (Jorissen, 1999); suspension feeders and sediment surface dwellers are very rare. Consequently, our FIEI index, corresponding to the accumulative percentage of opportunistic and stress-tolerant taxa, is necessarily based on the differential response of the various taxa to environmental impact. In this study, the response to ecosystem perturbation of the various taxa has been determined on the basis of their distributional patterns in this study area, and on a comparison of the living faunas with the fossilised subrecent faunas, supposed to represent the pre-impact, natural conditions (Mojtahid et al., 2006). The risk of this method is that it could lead to a certain degree of circular reasoning. However, it presents the strong advantage that the selection of indicator species is based on the local conditions. This is especially important, because in different settings, a foraminiferal (or macrofaunal) species will not always respond in the same way to ecosystem enrichment. Generally, species will only show an opportunistic response to ecosystem enrichment if the trophic level of the natural ecosystem is below their preferred range. In case the trophical level of the natural environment already coincides with their preferred trophic range, a further ecosystem enrichment will cause a diminution of their standing stocks, and their ultimate 
disappearance from the ecosystem. This is exactly what causes the succession of opportunistic species along our sample transect. In conclusion, not a single species will systematically show an opportunistic response to ecosystem enrichment, and generalisations in this sense are necessarily too simplistic.

When we compare the results of the macrofaunal ITI and the foraminiferal FIEI for 2003 (Fig. 13), the overall pattern is very similar. Looking in more detail at the two curves, two clear differences appear.

First, the macrofaunal ITI indicates a maximal environmental impact at station 6 , whereas the foraminiferal FIEl suggest that environmental stress is maximal at station 13 . We think that the slightly lower FIEI value at station 6 is mainly caused by the extreme poverty at the foraminiferal faunas at this station, which in itself is indicative of severe environmental stress. Next, the ITI suggests that in 2003, there was a very sharp boundary between station 4, 230 S of the disposal site, which was still clearly impacted, and stations S3 and S16, at 470 and 730 from the disposal site, respectively, which appear to be unaffected by oil activities. On the contrary, the foraminiferal FIEI shows a very gradual trend of decreasing values until the reference station S2. The foraminiferal faunas at stations S3 and S16 still suggest a moderate environmental impact.

We think that this difference can be explained in two ways. A first possibility is that the foraminiferal faunas are more sensitive to low levels of environmental perturbation than the macrofauna. This was previously suggested by Mojtahid et al. (2008). The second possibility could be that the difference between ITI and FIEI is due to the different strategies used in these two methods. The most important difference is that the FIEI uses a "a priori" grouping of macrofaunal taxa in 4 categories. Several authors (e.g. Wildish, 1984; Grall \& Hily, 2003) have indicated that it may be problematical to assign some taxa to trophic groups, because of a lack of information for some species and contradictory literature evidence for others. It has also been suggested (REFS) that macrofaunal taxa may change their feeding behavior in function of the environmental conditions. As explained earlier, in the foraminiferal FIEI index, the selection of tolerant and/or opportunistic marker species is based on an analysis of the spatial trends in the study area, and on a comparison of living and dead (pre-impacted) faunas. This method has the evident advantage that it takes better into account the local environmental conditions, but has the potential disadvantage that it may lead to circular reasoning.

In order to find out whether these different strategies cause the difference between ITI and FIEI at stations S3 and S16, we decided to apply our FIEI method to the macrofaunal data of 2003. However, it should be taken into account that this method is less suitable for macrofauna, because it is impossible to compare recent and dead faunas, allowing the recognition of recent faunal additions and/or disappearances at each site. Therefore, our selection of opportunistic and/or tolerant macrofaunal marker species is entirely based on the observed spatial patterns. The resulting macrofaunal curve (Fig. 14) is very similar to the FIEl curve, suggesting that macrofauna has the same sensitivity as foraminifera, and that sites S3 and S16 are still moderately impacted. A difference between the foraminiferal and macrofaunal curves can be noticed at the most impacted sites, where the macrofaunal index rises to values above 90\%, whereas the FIEI values are between 70 and $90 \%$. This difference is probably due to the fact that sensitive macrofaunal taxa have completed disappeared at these sites, whereas the more sensitive foraminiferal taxa are still present, albeit in lower numbers.

\section{Conclusions}

Macrofauna and foraminifera can both be used as bio-indicators of environmental impact of offshore oil drilling activities. 
In macrofauna, a wide spectrum of sensitive to opportunistic and tolerant taxa exists, which show important differences in spatial distribution. Also the foraminiferal community contains a number of tolerant and/or opportunistic taxa. However, species very sensitive to drill mud disposal are not very prominent. If such species exist, they are not dominating the natural faunas at unimpacted sites.

Most macrofaunal indices of environmental impact are based on a priori groupings of indicator species, either in function of tolerance levels, or of feeding behaviour. In the case of our foraminiferal FIEI index, indicator species are selected on the basis of the observed spatial patterns in the study area, and our selection has been comforted by a comparison of recent and dead (pre-impacted) faunas.

At first sight, the foraminiferal bio-indicator method appears to be more sensitive than the macrofaunal ITI. At sites positioned at 500 to $750 \mathrm{~m}$ from the disposal site, the ITI does no longer show an environmental impact, whereas the FIEC still suggests moderate environmental perturbation.

However, it appears that in case macrofaunal marker species are selected in function of the spatial patterns in the study areas, the sensitivity of the macrofauna becomes similar to that of the foraminiferal faunas. Unfortunately, since most macrofauna remains are not preserved in the fossil record, it is not possible to use the comparison of recent and fossil faunas to confirm the choice of marker species.

In view of the larger sensibility of the Foraminiferal Index of Environmental Impact, it appears that there is a clear bonus to add the study of the foraminiferal assemblages to the more commonly used study of macrofauna.

\section{References}

Alve, E. 1995. Benthic foraminiferal responses to estuarine pollution: a review. Journal of Foraminiferal Research. 25, 190-203.

Barmawidjaja, D. M., van der Zwaan, G. J., Jorissen, F. J., Puskaric, S., 1995. 150 years of eutrophication in the northern Adriatic Sea: Evidence from a benthic foraminiferal record. Marine Geology. Volume 122, Issue 4, February 1995, 367-384.

Bergin, F., Kucuksezgin, F., Uluturhan, E., Barut, I.F., Meric, E., Avsar, N., Nazik, A., 2006. The response of benthic foraminifera and ostracoda to heavy metal pollution in Gulf of Izmir (Eastern Aegean Sea). Estuarine, Coastal and Shelf Science. 66, 368-386.

Bhalla, S. N., Nigam R., 1986. Recent foraminifera from polluted marine environment of Velsao Beach, South Goa, India. Revue de Paleobiologie. 5, 43-46.

Borja, A. , Muxika, I., Franco, J.,2003. The application of a Marine Biotic Index to different impact sources affecting soft-bottom benthic communities along European coasts. Marine Pollution Bulletin. 46, 835-845.

Borja, A., Muxika, I., 2005. Guidelines for the use of AMBI (AZTI's Marine Biotic Index) in the assessment of the benthic ecological quality. Marine Pollution Bulletin. Volume 50 , Issue 7 , July 2005, 787-789.

Breuer, E., Stevenson, A.G., Howe, J.A., Carroll, J., Shimmield, G.B., 2004. Drill cutting accumulations in the Northern and Central North Sea: a review of environmental interactions and chemical fate. Marine Pollution Bulletin. 48, 12-25.

Burone,L., Venturini, N., Sprechmann, P., Valente,P., Muniz, P., 2006. Foraminiferal responses to polluted sediments in the Montevideo coastal zone, Uruguay. Marine Pollution Bulletin. 52, 61-73.

Cadre, V.L., Debenay, J.-P., Lesourd, M., 2003. Low pH effects on Ammonia baccarii test deformation: implications for using test deformations as a pollution indicator. $\mathrm{J}$ Foraminiferal Res. 33, 1-9.

Chow, T.J., 1976. Barium in Southern California Coastal Waters: A Potential Indicator of Marine Drilling Contamination. Science. 193. no. 4247, 57-58. 
Coccioni, R., 2000. Benthic foraminifera as bioindicators of heavy metal pollution-a case study from the Goro Lagoon (Italy). In: R.E. Martin, Editor, Environmental Micropaleontology. 71-103.

Daan, R., Mulder, M., Vanleeuwen, A., 1994. Differential sensitivity of macrozoobenthic species to discharges of oil contaminated drill cuttings in the North Sea. Netherlands Journal of Sea Research. 33, 113-127

Dalmazzone, Ch., Blanchet, D., Lamoureux, S., Dutrieux, E., Durrieu, J., Camps, R., Galgani, F., 2004. Impact of Drilling Activities in Warm Sea: Recolonization Capacities of SeabedOil \& Gas Science and Technology - Rev. IFP, Vol. 59 (2004), No. 6, 625-647.

Davies, M., Addy, J.M., Blackman, R.A.,Blanchard, J.R., Ferbrache, J.E., Moore, D.C., Somerville, H.J., Whitehead, A., Wilkinson, T., 1984. Environmental effects of the use of oilbased drilling muds in the North Sea. Marine Pollution Bulletin. 15, 363-370.

de Nooijer, L.J., Reichart, G.J., Dueñas-Bohórquez, A., Wolthers, M., Ernst, S.R., Mason, P.R.D. , van der Zwaan, G.J., 2007. Copper incorporation in foraminiferal calcite: results from culturing experiments. Biogeosciences. 4, 493-504.

De Rijk, S., Jorissen, F.J., Rohling, E.J., Troelstra, S.R., 2000. Organic flux control on bathymetric zonation of Mediterranean benthic foraminifera. Marine Micropaleontology. 40, 151-166.

Dicks, B., Bakke, T., Dixon, I.M.T., 1988. Oil exploration and production and oil spills. In: W. Salomons, B.L. Bayne, E.K. Duursma and U. Förstner, Editors, Pollution of the North Sea: An Assessment, Springer, Berlin (1988), pp. 524-537.

Durrieu, J., Bouzet, Ph., 2004. Seabed recolonisation : N'Kossa Case. SPE Paper 86710 Calgary, Alberta, Canada, 29-31 March 2004.

Durrieu, J., Mojtahid, M., Cazes, L., Galgani, F., Jorissen, F., Tran, D., Camps, R.,2006. Aged Drilled Cuttings Offshore Gabon: New Methodology for Assessing Their Impact. Society of Petroleum Engineers Inc. SPE. 98414, pp. 8.

Ernst, S.R., Morvan, J., Geslin, E., Le Bihan, A., Jorissen, F.J., 2006. Benthic foraminiferal response to experimentally induced Erika oil pollution. Marine Micropaleontology. 61, 76-93.

Flaten, G.R., Botnen, H., Grung, B., Kvalheim, O.M., 2007. Quantifying disturbance in benthic communities-comparison of the community disturbance index (CDI) to other multivariate methods. Ecological Indicators. 7, 254-276.

Gage, J.D., 2001. Deep-sea benthic community and environmental impact assessment at the Atlantic Frontier. Continental Shelf Research. 21, 357-986.

Gass, S.E., Roberts, J.M., 2006. The occurrence of the cold-water coral Lophelia pertusa (Scleractinia) on oil and gas platforms in the North Sea: colony growth, recruitment and environmental controls on distribution. Marine Pollution Bulletin. 52, 549-559.

Grall, J., Hily, C., 2003. REBENT, Traitement des données stationnelles (faune), décembre 2003.

Gray, J.S., Clarke, K.R., Warwick, R.M., Hobbs, G., 1990. Detection of initial effects of pollution on marine benthos-an example from the Ekofisk and Eldfisk oilfields, North Sea, Marine Ecology Program Series. 66, 285-299.

Gustafson, M., Ingela, D.F., Blanck, H., Hall, P., Molander, S., Nordberg, K., 2000. Benthic foraminiferal tolerance to Tri- $n$-Butyltin (TBT) pollution in an experimental mesocosm. Marine Pollution Bulletin. 40, 1072-1075.

Huang, B., Jian, Z., Cheng, X., Wang, P., 2002. Foraminiferal responses to upwelling variations in the South China Sea over the last 220000 years. Marine Micropaleontology. 47, $1-15$.

Kennicutt, M. C., Keeney-Kennicutt, W. L., Bresley, B. J. , Fenner, F., 2006. The use of pyrolysis and barium distributions to assess the areal extent of drilling fluids in surficial marine sediments. Environmental Geology. 4, 239-249.

Kuhnt, W., Hess, S., Jian, Z., 1999. Quantitative composition of benthic foraminiferal assemblages as a proxy indicator for organic carbon flux rates in the South China Sea. Marine Geology. 156 (1-4), 123-158. 
Locklin, J.A., Maddocks, R.F., 1982. Recent foraminifera around petroleum production platforms on the southwest Louisiana shelf. Gulf Coast Association of Geological Societies Transactions. 32, 377-397.

Lutze, G.F., 1986. Uvigerina species of the eastern North Atlantic. In: Van der Zwaan, G.J., Jorissen, F.J., Verhallen, P.J.J.M., von Daniels, C.H. (Eds.), Atlantic-European Oligocene to Recent Uvigerina. Utrecht Micropaleontological Bulletins, vol. 35, pp. 21-46.

Lutze, G.F., Coulbourn, W.T., 1984. Recent benthic foraminifera from the continental margin of northwest Africa: community structure and distribution. Marine Micropaleontology. 8, 361401

Mackay, D. W., Halcrow, W., Thornton, I, 1972. Sludge dumping in the firth of Clyde. Marine Pollution Bulletin. 3, 7-10.

Mackensen, A., Schmiedl, G., Harloff, J., Giese, M., 1995. Deep-sea foraminifera in the South Atlantic Ocean: ecology and assemblage generation. Micropaleontology. 41 (4), 342358.

Mackie et al, 1993 , the macrobenthic infauna of hoi ha wan and tolo channel hong kong.

Maurer, D., Nguyen, H. , Robertson, G., Gerlinger, T., 1999. The infaunal trophic index (ITI): its suitability for marine environmental monitoring. Ecological Application. 9, 699-713.

Mojtahid, M., Jorissen, F., Durrieu, J., Galgani, F., Howa, H., Redois, F., Camps, R., 2006. Benthic foraminifera as bio-indicators of drill cutting disposal in tropical east Atlantic outer shelf environments. Marine Micropaleontology. 61, Issues 1-3, 58-75.

Mojtahid, M., Jorissen, F.J., Pearson, T.H., 2008. Comparison of benthic foraminiferal and macrofaunal responses to organic pollution in the Firth of Clyde (Scotland). Marine Pollution Bulletin. 56, 42-76.

Murray, J., 2006. Ecology and applications of benthic foraminifera. Cambridge University Press.

Muxika, I., Borja, A., Bonne, W., 2005. The suitability of the marine biotic index (AMBI) to new impact sources along European coasts. Ecological Indicators. 5, 19-31.

Nagy, J. and Alve, E., 1987. Temporal changes in foraminiferal faunas and impact of pollution in Sandebukta, Oslo Fjord. Marine Micropaleontology. 12,109-128.

Neff, J.M., 1987. Biological effects of drilling fluids, drilling cuttings and produced waters. In: Boesch, D.F., Rabalais, N.N. (Eds.), Long term environmental effect of offshore oil and gas development. Elsevier Applied Science Publishers, London, 469-538.

Neff, J.M., 2005. Composition, environmental fates and biological effects of water based drilling muds and cuttings discharged to the marine environment : A Synthesis and Annotated Bibliography. Batelle report to Petroleum Environmental Research Forum (PERF) and American Petroleum Institute. 73 pp.

Olsen, G.H., Sva, E., Carroll, J.L., Camus, L., De Coen, W., Smolders, R., Øveraas, H., Ketil Hyllan, K., 2007. Alterations in the energy budget of Arctic benthic species exposed to oilrelated compounds. Aquatic Toxicology. 83, 85-92.

Olsgard, F., Gray, J.S., 1995. A comprehensive analysis of the effects of offshore oil and gas exploration and production on the benthic communities of the Norwegian continental shelf. Marine Ecological Progress Series. 122, 277-306.

Parr, T.D., Tait, R.D., Maxon, C.L., Newton, F.C., Hardin, J.L., 2007. A descriptive account of benthic macrofauna and sediment from an area of planned petroleum exploration in the southern Caspian Sea. Estuarine, Coastal and Shelf Science. 71, 170-180.

Pearson, T.H., Rosenberg, R., 1978. Macrobenthic succession in relation to organic enrichment and pollution of the marine environment. Oceanography and Marine Biology Annual Review. 16, 229-311.

Pearson, T.H., 1985. Benthic ecology in an accumulating sludge-disposal site. Proceedings of the fourth International Ocean Disposal Symposium, England, April 1985, Chapter 17, 195-200.

Rao, K. K. and T. S. S. Rao. 1979. Studies on pollution ecology of foraminifera of the Trivandrum coast. Indian Journal of Marine Sciences. 8, 31-35. 
Saraswat, R., Kurtarkar, S.R., Mazumder, A., Nigam, R., 2004. Foraminifers as indicators of marine pollution: a culture experiment with Rosalina leei. Marine Pollution Bulletin. 48, 9196.

Schaanning, M., Trannum, H., Øxnevad, S., Carroll, J., Bakke, T., 2008. Effects of drill cuttings on biogeochemical fluxes and macrobenthos of marine sediments. Journal of Experimental Marine Biology and Ecology. 361, 49-57.

Schafer, C.T., 1970. Studies of Benthonic Foraminifera in the Restigouche Estuary: 1. Faunal Distribution Patterns near Pollution Sources. Maritime Sediments. 6(3), 121-134.

Schafer, C.T., 1982. Foraminiferal colonization of an offshore dump site in Chaleur Bay, New Brunswick, Canada. J. Foramin. Res. 12, 317-326.

Schafer, C. T., Collins, E. S., Smith, J. N.. 1991. Relationship of foraminifera and thecamoebian distributions to sediments contaminated by pulp mill effluent; Saguency Fiord, Quebec, Canada. Marine Micropalaeontology. 17, 255-283

Seiglie, 1968. Foraminiferal assemblages as indicators of high organic carbon content in sediments and of polluted waters. The american association of petroleum geologists bulletin, 52(11): 2231-2241.

Setty, M.G.A.P., 1976. The relative sensitivity of benthonic foraminifera in the polluted marine environment of Cola Bay, Goa. Indian Colloquium of Micropaleontology and Stratigraphy, Proc. VI: 225-234.

Setty, M.G.A.P. and Nigam, R., 1984. Benthic foraminifera as pollution indices in the marine environment of west coast of India. Rivista Italiana de Paleontoloia e Stratigrafi, 89(3): 421436.

Shimmield, G.B. Breuer, E., Cummings, D.G., Pepper, O., Shimmield, T., 2000. Contaminant Leaching from Drilling Cuttings Piles of the Northern and Central North Sea: Field Results from Beryl "A" Cuttings Pile. Scottish Association for Marine Science, pp. 28.

Venturini, N., Muniz, P., Bicego, M., Martins, C. ,Tommasi, L., 2008. Petroleum contamination impact on macrobenthic communities under the influence of an oil refinery: Integrating chemical and biological multivariate data. Estuarine, Coastal and Shelf Science. 78, 457-467.

Warwick, R.M., 1986. A new method for detecting pollution effects on marine macrobenthic communities. Marine Biology. 92, 557-562.

Watkins, J.G., 1961. Foraminiferal ecology around the Orange County, California, ocean sewer outfall. Micropaleontology. 7(2), 199-206.

Weston, P., 1990. Quantitative examination of macrobenthic community changes along an organic enrichment gradient. Marine Ecology Progress Series. 61, 233-244.

Wildish, D.J., 1984. Geographical distribution of macrofauna on sublittoral sediments of continental shelves : a modified trophic ratio concept. Proc. $19^{\text {th }}$ European Marine Biology Symposium. P.E. Gibbs, editeur, University of Cambridge Press, 335-345.

Word, J.Q., 1979. The infaunal trophic index. Annual report 1978 Southern California Coastal Water Research Project, Los Angeles, California, USA, pp. 19-41.

Zemel, B., 1995. Tracers in the oil field. Developments in petroleum science 43, pp. 419. 


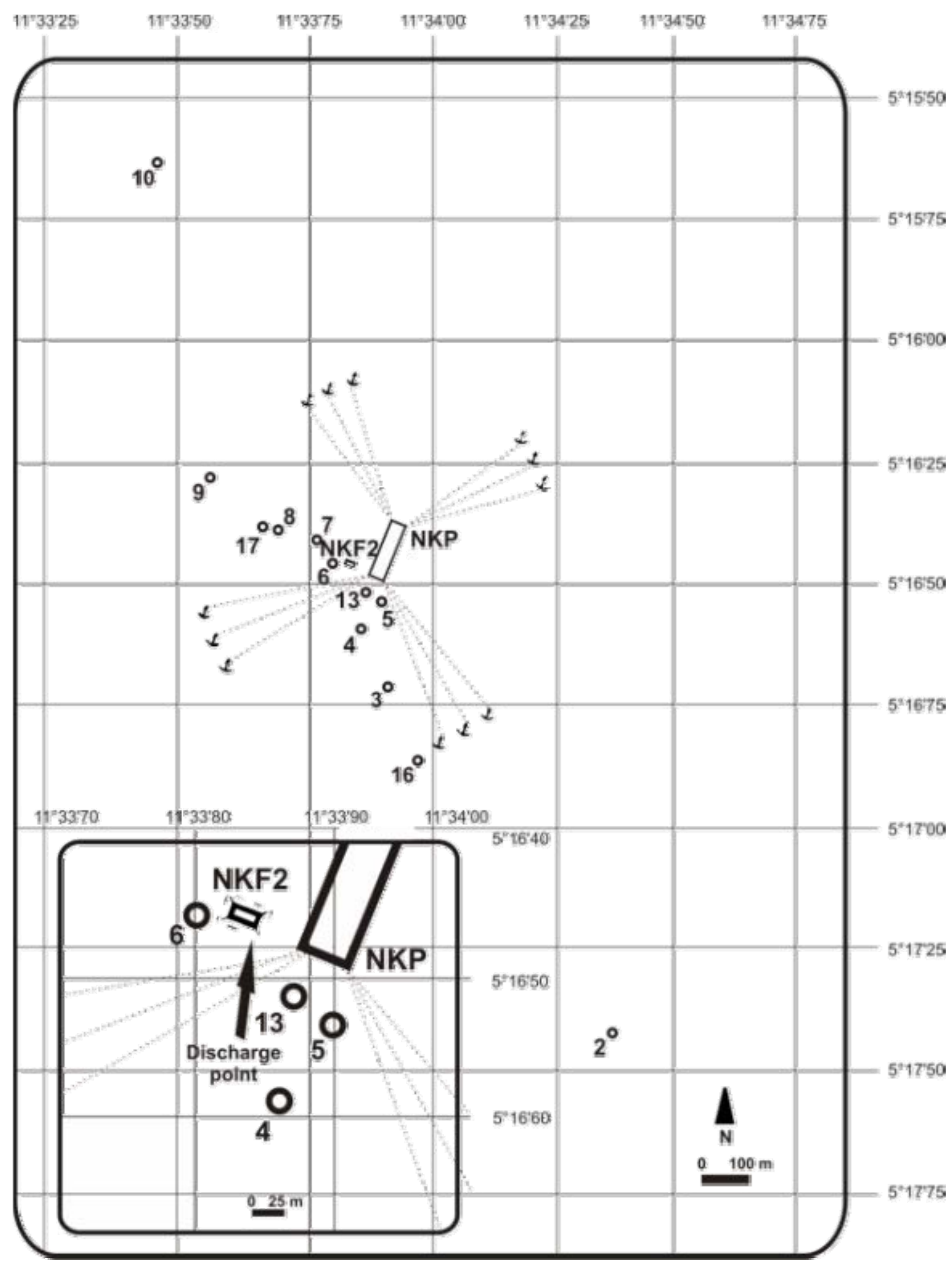

Fig. 1. Map of the N'Kossa oil field, platforms NKP and NKF2, and the 14 sampling stations used in this study. 


\begin{tabular}{|c|c|c|c|c|c|c}
\hline Station & Latitude & Longitude & $\begin{array}{c}\text { Position } \\
\text { with respect } \\
\text { to the } \\
\text { discharge } \\
\text { point } \\
\text { (NFK2) }\end{array}$ & $\begin{array}{c}\text { Macrofauna } \\
\mathbf{2 0 0 0}\end{array}$ & $\begin{array}{c}\text { Macrofauna } \\
\mathbf{2 0 0 2}\end{array}$ & $\begin{array}{c}\text { Macrofauna } \\
\text { and } \\
\text { Foraminifera } \\
\mathbf{2 0 0 3}\end{array}$ \\
\hline $\mathbf{1 1}$ & $5^{\circ} 13,848 \mathrm{~S}$ & $11^{\circ} 32,772 \mathrm{E}$ & $5300 \mathrm{~m} \mathrm{~N}$ & $\mathrm{X}$ & & \\
\hline $\mathbf{1 0}$ & $5^{\circ} 15,462 \mathrm{~S}$ & $11^{\circ} 33,447 \mathrm{E}$ & $2000 \mathrm{~m} \mathrm{~N}$ & $\mathrm{X}$ & & \\
\hline $\mathbf{9}$ & $5^{\circ} 16,285 \mathrm{~S}$ & $11^{\circ} 33,568 \mathrm{E}$ & $500 \mathrm{~m} \mathrm{WNW}$ & $\mathrm{X}$ & & \\
\hline $\mathbf{1 7}$ & $5^{\circ} 16,365 \mathrm{~S}$ & $11^{\circ} 33,654 \mathrm{E}$ & $450 \mathrm{~m} \mathrm{WNW}$ & & & $\mathrm{X}$ \\
\hline $\mathbf{8}$ & $5^{\circ} 16,401 \mathrm{~S}$ & $11^{\circ} 33,682 \mathrm{E}$ & $300 \mathrm{~m} \mathrm{WNW}$ & $\mathrm{X}$ & & \\
\hline $\mathbf{7}$ & $5^{\circ} 16,425 \mathrm{~S}$ & $11^{\circ} 33,765 \mathrm{E}$ & $150 \mathrm{~m} \mathrm{WNW}$ & $\mathrm{X}$ & & $\mathrm{X}$ \\
\hline $\mathbf{6}$ & $5^{\circ} 16,453 \mathrm{~S}$ & $11^{\circ} 33,802 \mathrm{E}$ & $70 \mathrm{~m} \mathrm{~W}$ & $\mathrm{X}$ & $\mathrm{X}$ & $\mathrm{X}$ \\
\hline $\mathbf{1 3}$ & $5^{\circ} 16,519 \mathrm{~S}$ & $11^{\circ} 33,874 \mathrm{E}$ & $100 \mathrm{~m} \mathrm{~S}$ & & $\mathrm{X}$ & $\mathrm{X}$ \\
\hline $\mathbf{5}$ & $5^{\circ} 16,529 \mathrm{~S}$ & $11^{\circ} 33,897 \mathrm{E}$ & $175 \mathrm{~m} \mathrm{SSE}$ & $\mathrm{X}$ & & $\mathrm{X}$ \\
\hline $\mathbf{4}$ & $5^{\circ} 16,588 \mathrm{~S}$ & $11^{\circ} 33,861 \mathrm{E}$ & $230 \mathrm{~m} \mathrm{~S}$ & $\mathrm{X}$ & $\mathrm{X}$ & $\mathrm{X}$ \\
\hline $\mathbf{3}$ & $5^{\circ} 16,711 \mathrm{~S}$ & $11^{\circ} 33,916 \mathrm{E}$ & $470 \mathrm{~m} \mathrm{~S}$ & $\mathrm{X}$ & $\mathrm{X}$ & $\mathrm{X}$ \\
\hline $\mathbf{1 6}$ & $5^{\circ} 16,839 \mathrm{~S}$ & $11^{\circ} 33,966 \mathrm{E}$ & $730 \mathrm{~m} \mathrm{SSE}$ & & $\mathrm{X}$ & $\mathrm{X}$ \\
\hline $\mathbf{2}$ & $5^{\circ} 17,419 \mathrm{~S}$ & $11^{\circ} 34,379 \mathrm{E}$ & $2000 \mathrm{~m} \mathrm{SSE}$ & $\mathrm{X}$ & $\mathrm{X}$ & \\
\hline $\mathbf{1}$ & $5^{\circ} 18,376 \mathrm{~S}$ & $11^{\circ} 34,792 \mathrm{E}$ & $4000 \mathrm{~m} \mathrm{SSE}$ & $\mathrm{X}$ & & \\
\hline & & & & & & \\
\hline
\end{tabular}

Table 1. Geographical position and water depth of the 14 sampling stations used for the study of macrofauna (sampled in 2000, 2002 and 2003) and foraminifera (sampled in 2003) 

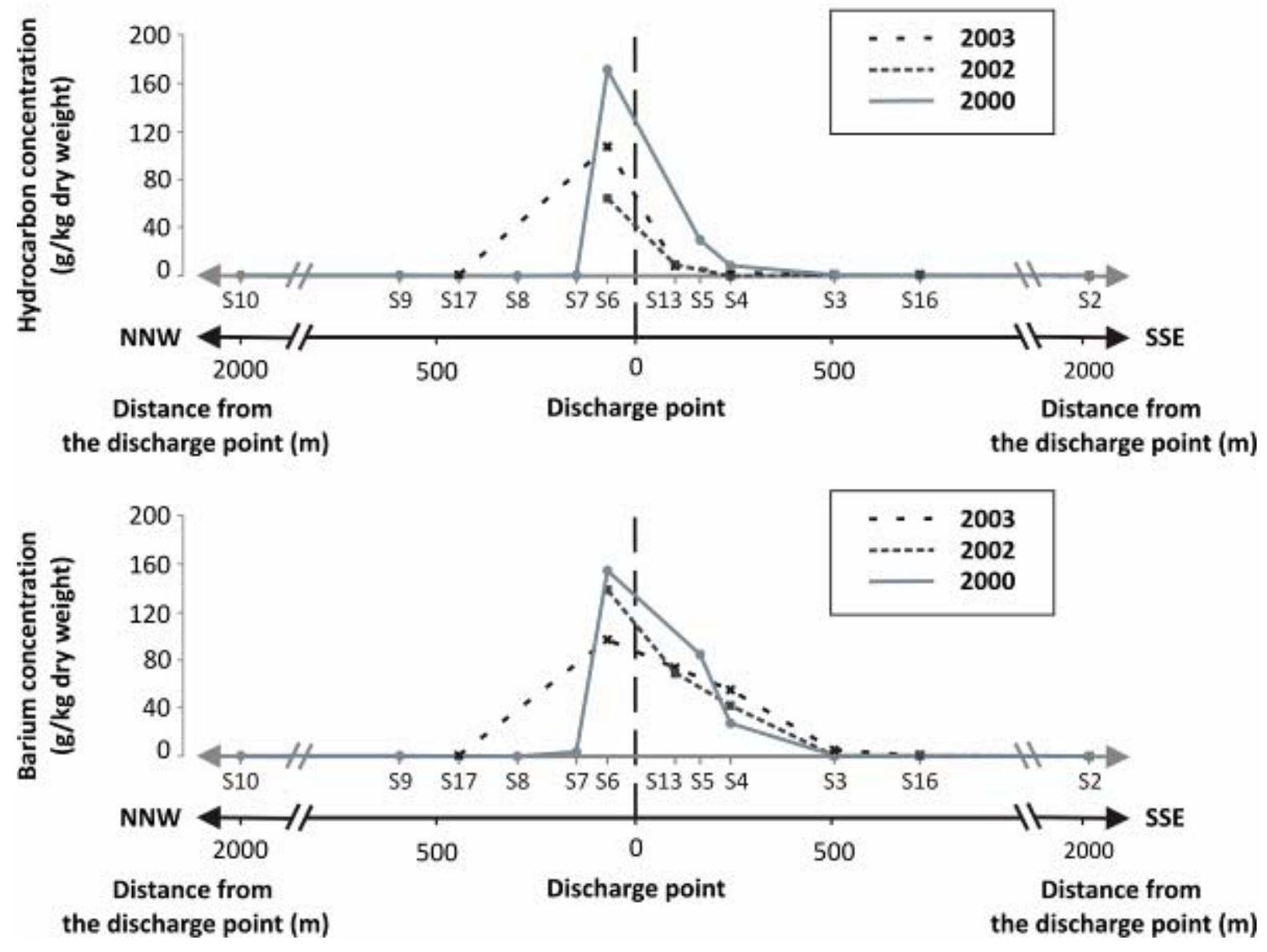

Fig. 2. Concentration of total hydrocarbons and total barium ( $\mathrm{g} / \mathrm{kg}$ dry weight) in the sediment, in function of the distance from the discharge point in 2000, 2002 and 2003 (After Dalmazzone et al., 2004, Durrieu and Bouzet, 2004) 


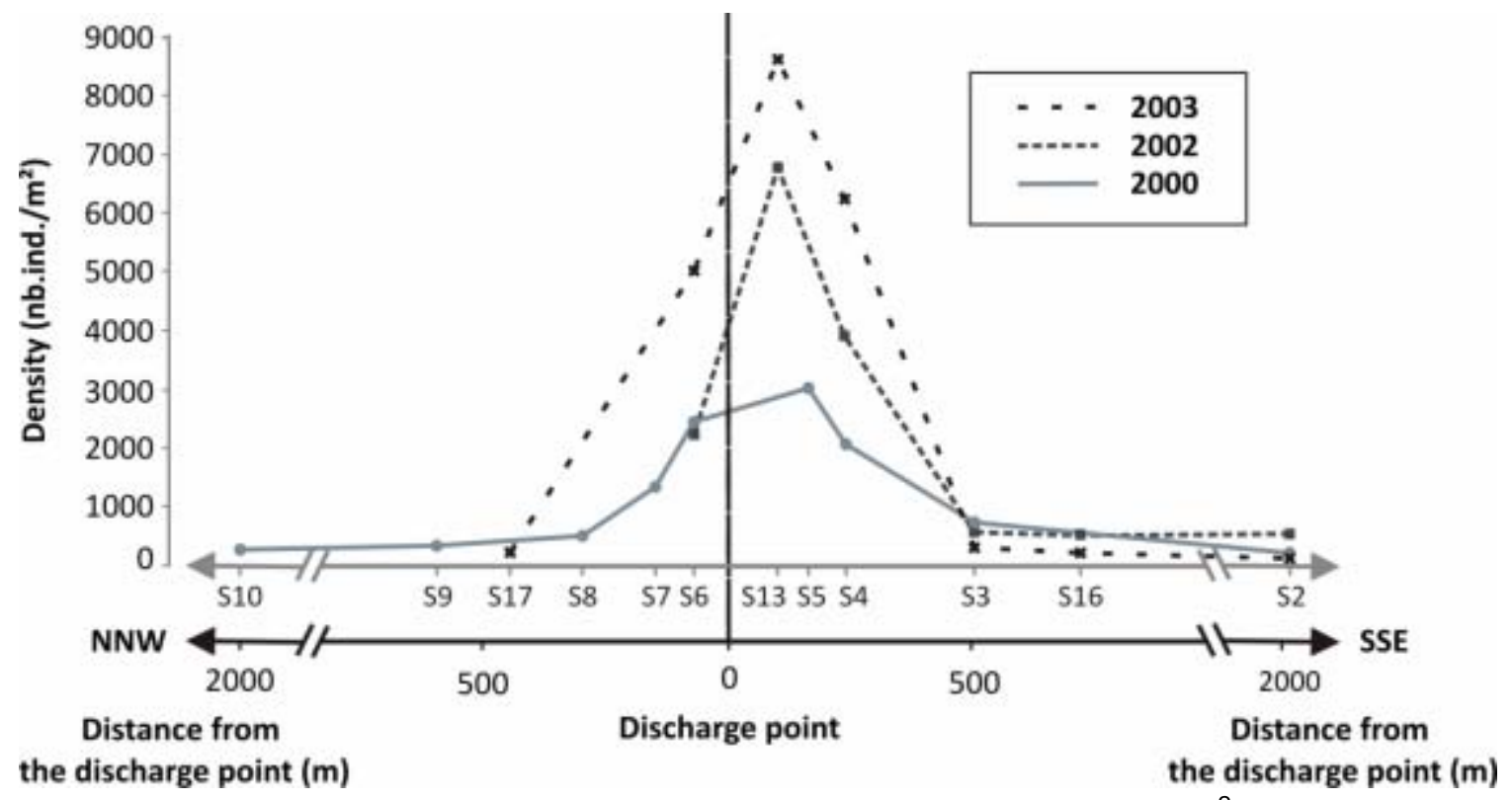

Fig. 3. Total densities of macrofauna (number of individuals per $\mathrm{m}^{2}$ ) at the 12 stations sampled in 2000, 2002 and 2003

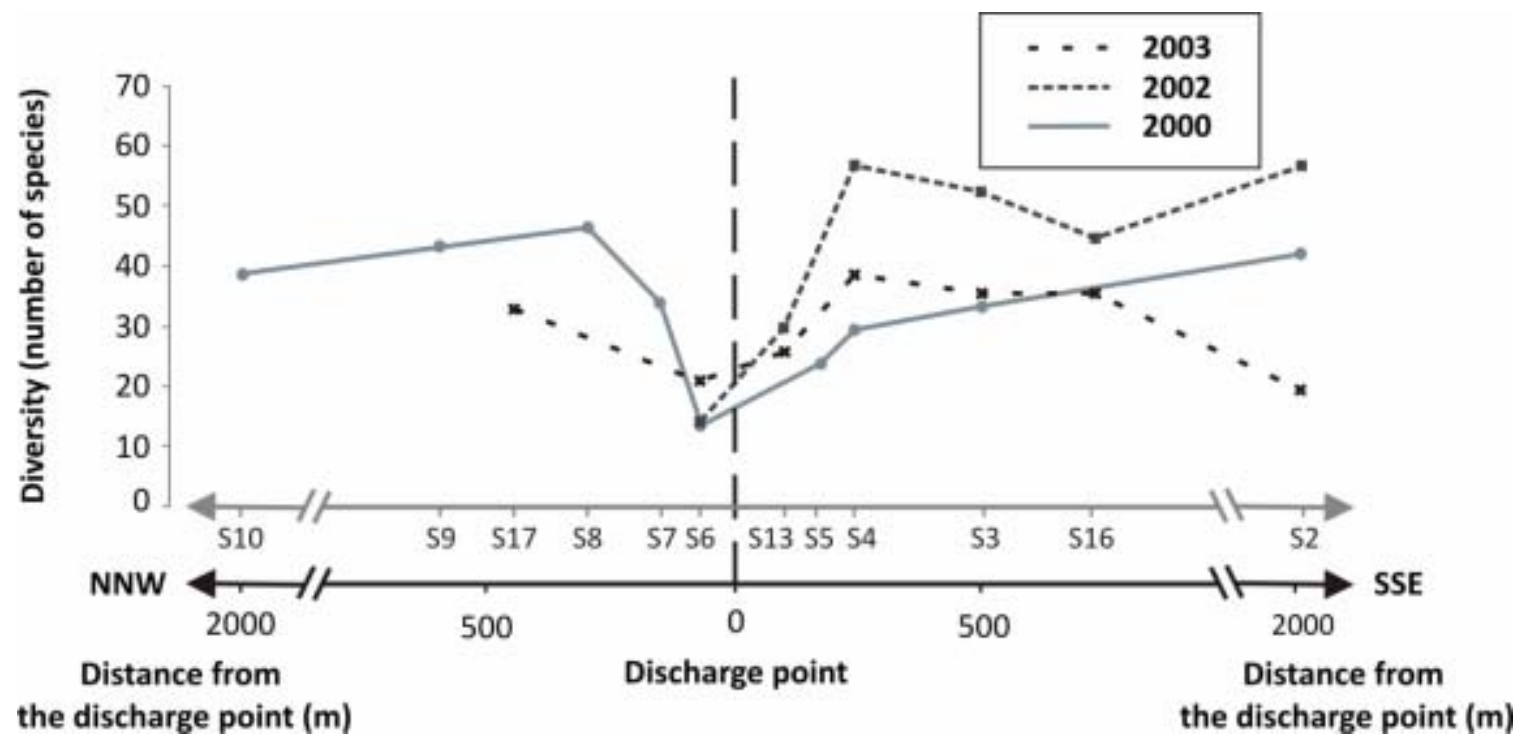

Fig. 4. Distribution of macrofaunal species richness values (number of species per station) at the 12 stations sampled in 2000, 2002 and 2003 


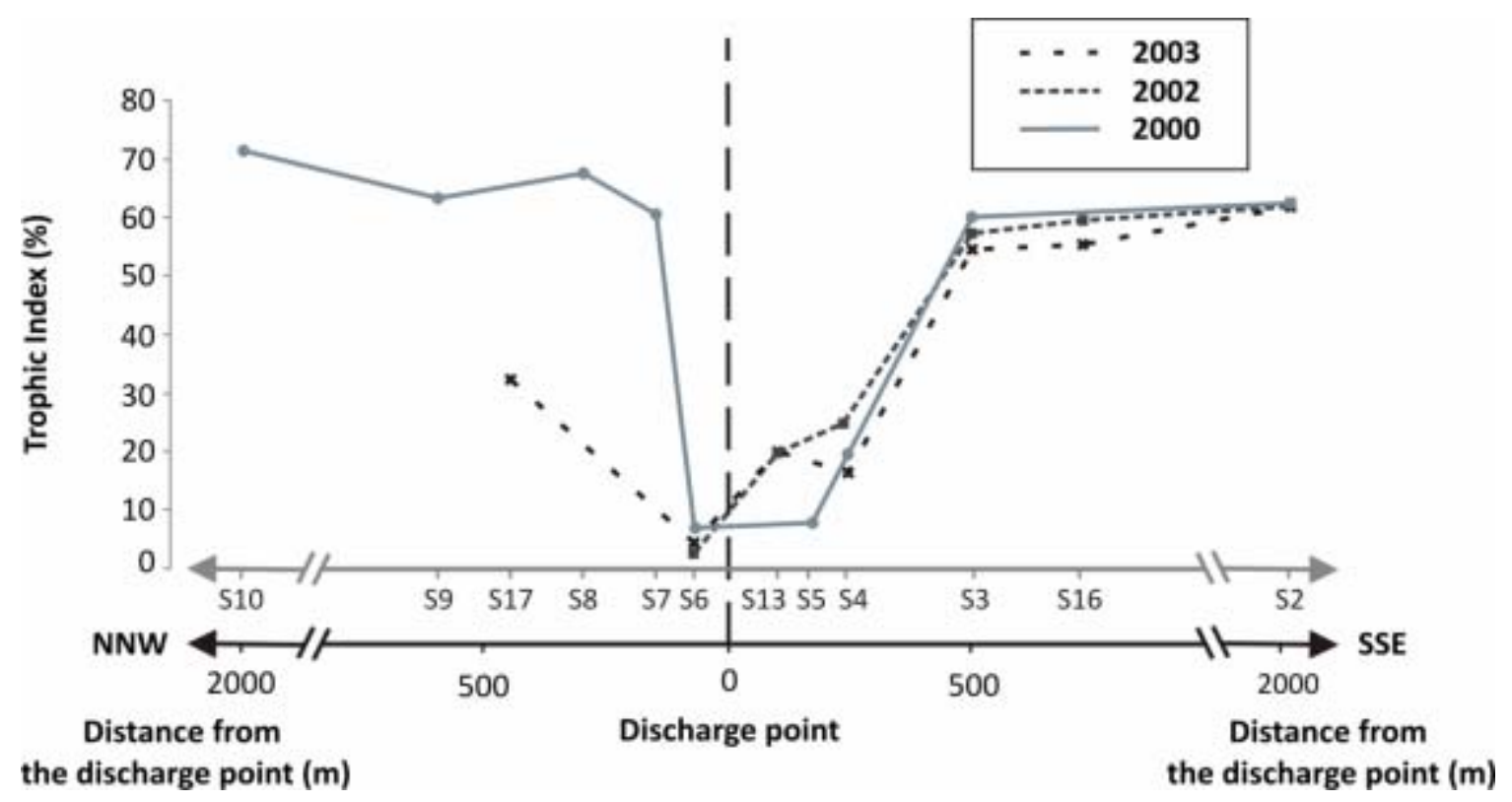

Fig. 5. Values of the trophic index (in \%) at the 12 stations sampled in 2000, 2002 and 2003

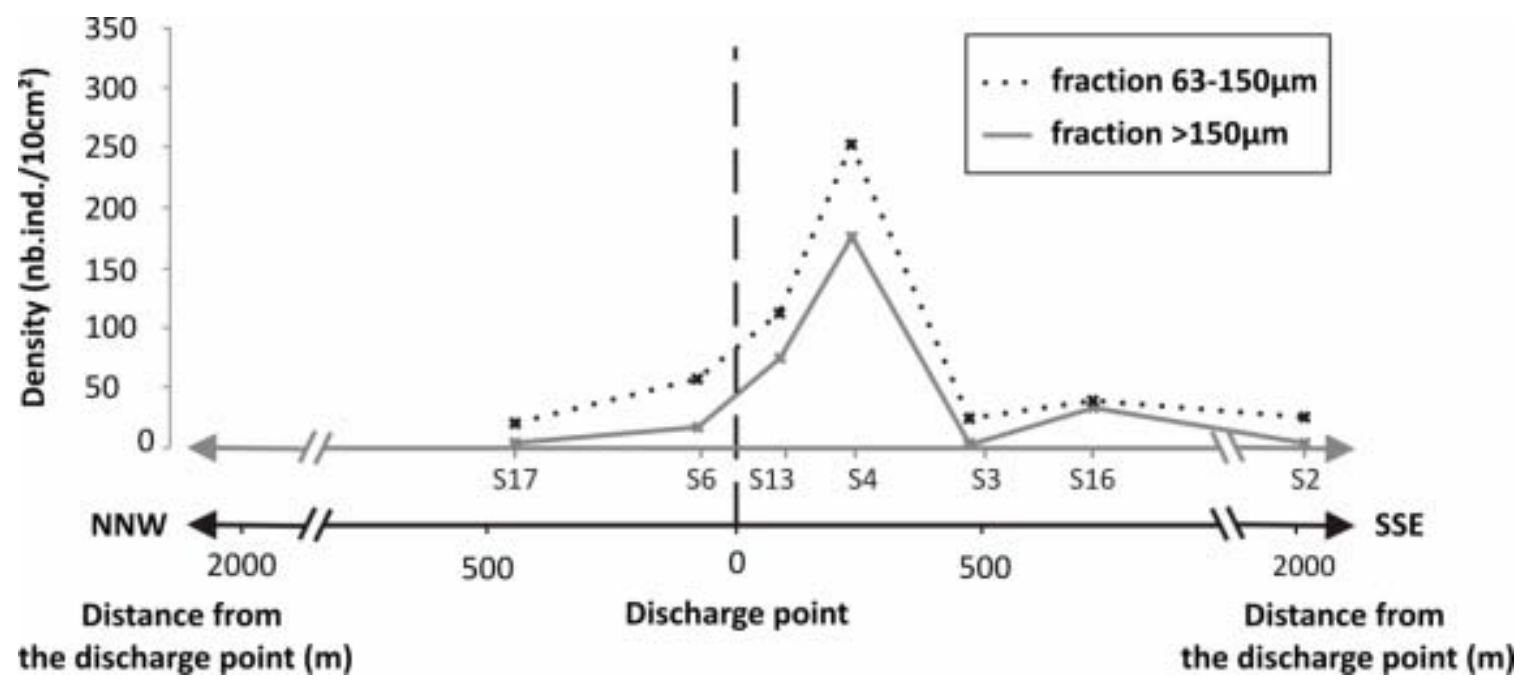

Fig. 6. Density of living benthic foraminifera $(>150 \mu \mathrm{m}$ and $63-150 \mu \mathrm{m}$ fractions) sampled in 2003 , standardized for a $10 \mathrm{~cm}^{2}$ sediment surface. 


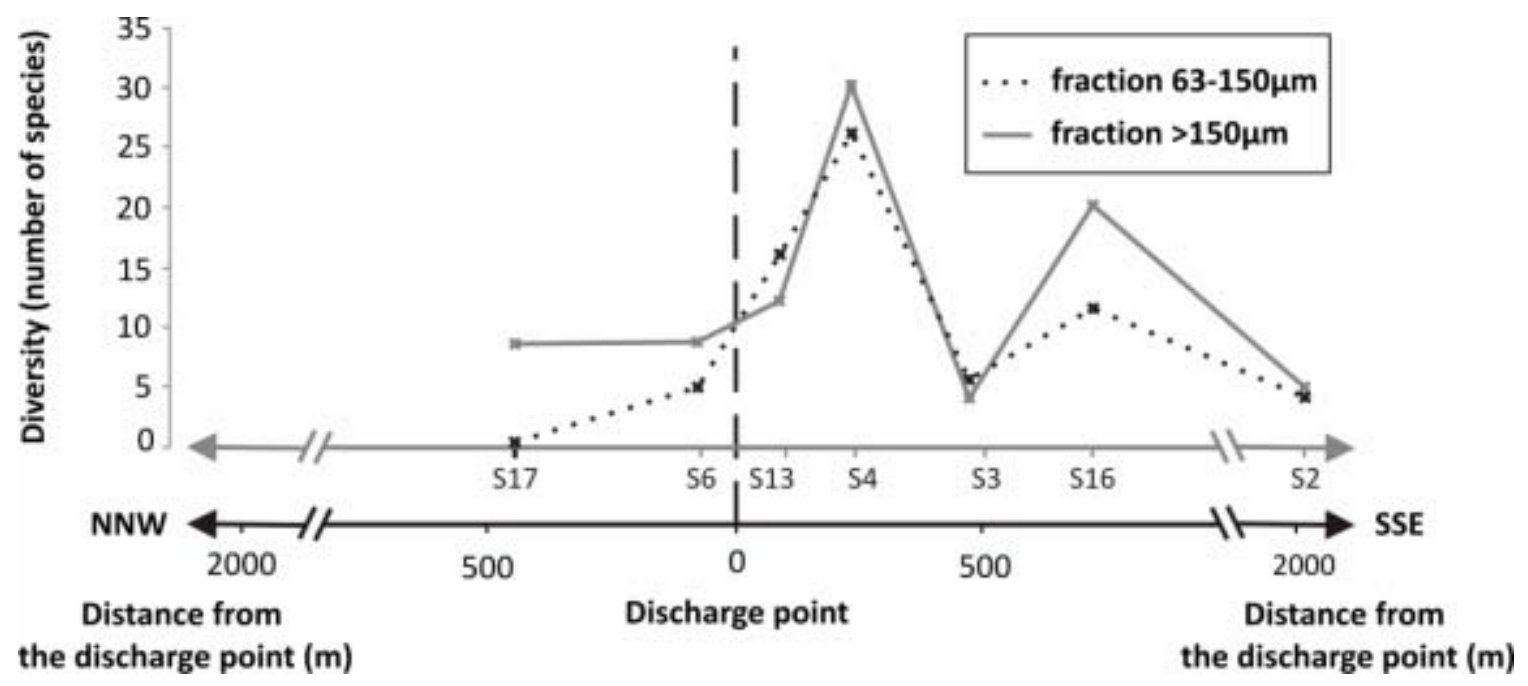

Fig. 7. Species numbers of living benthic foraminiferal faunas (>150 $\mu \mathrm{m}$ and $63-150 \mu \mathrm{m}$ fractions) at the seven sampling stations

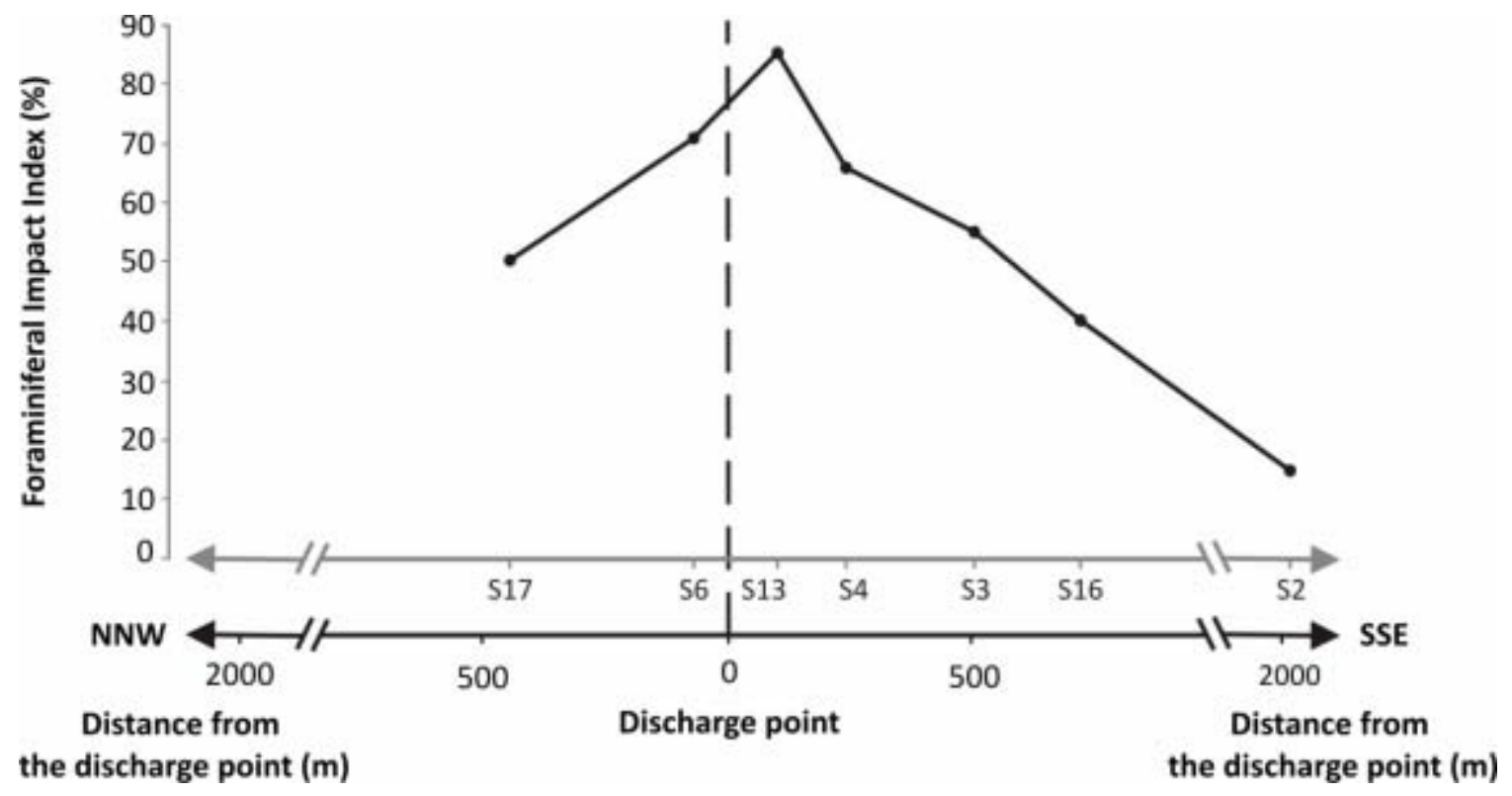

Fig. 8. Values of the Foraminiferal Impact Index (in \%) at the 7 stations sampled in 2003 

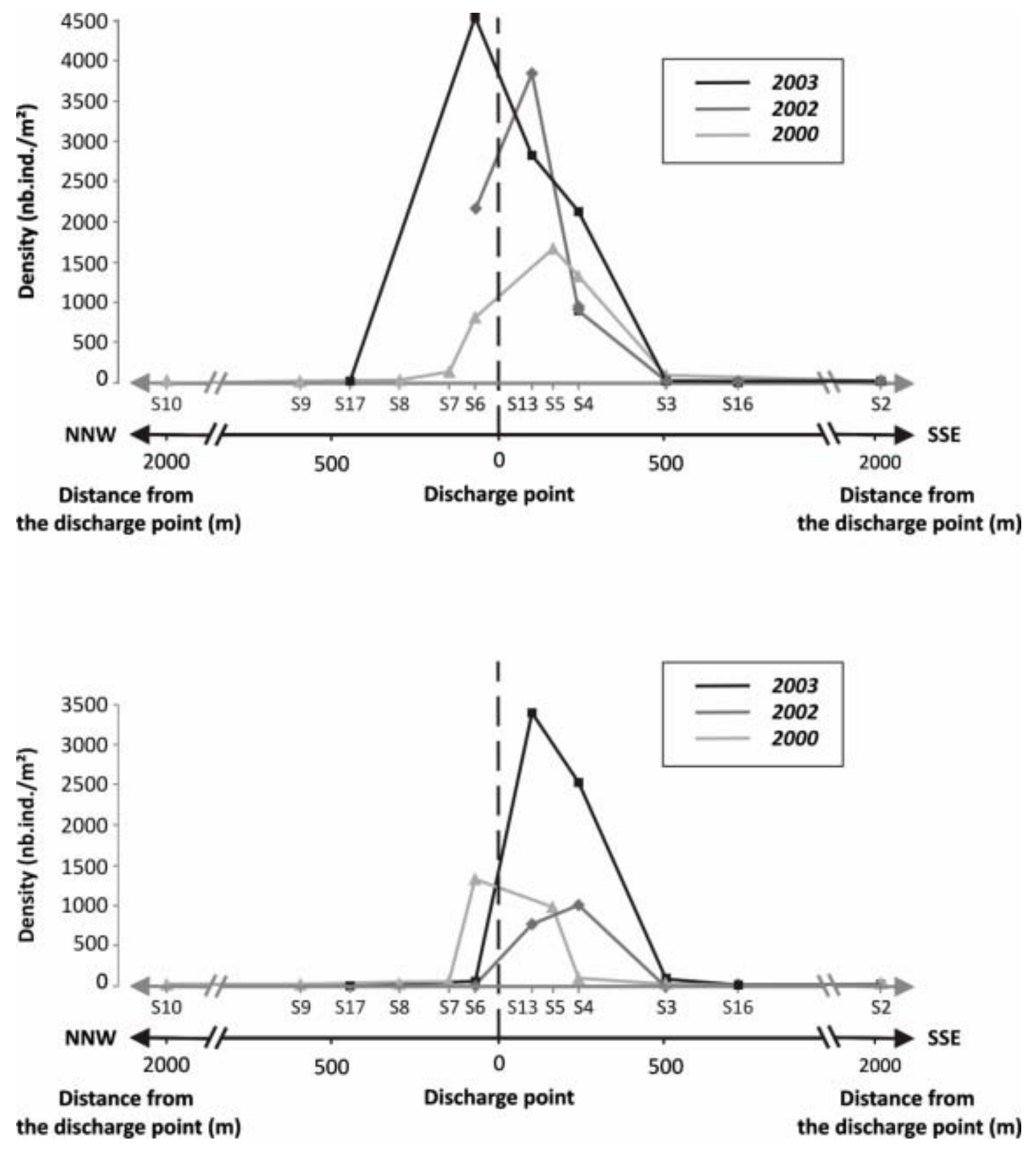

Fig. 9. Average densities of the indicator species Sigambra sp. and Capitella capitata (number of individuals per $\mathrm{m}^{2}$ ) at the 12 stations sampled in 2000, 2002 and 2003 

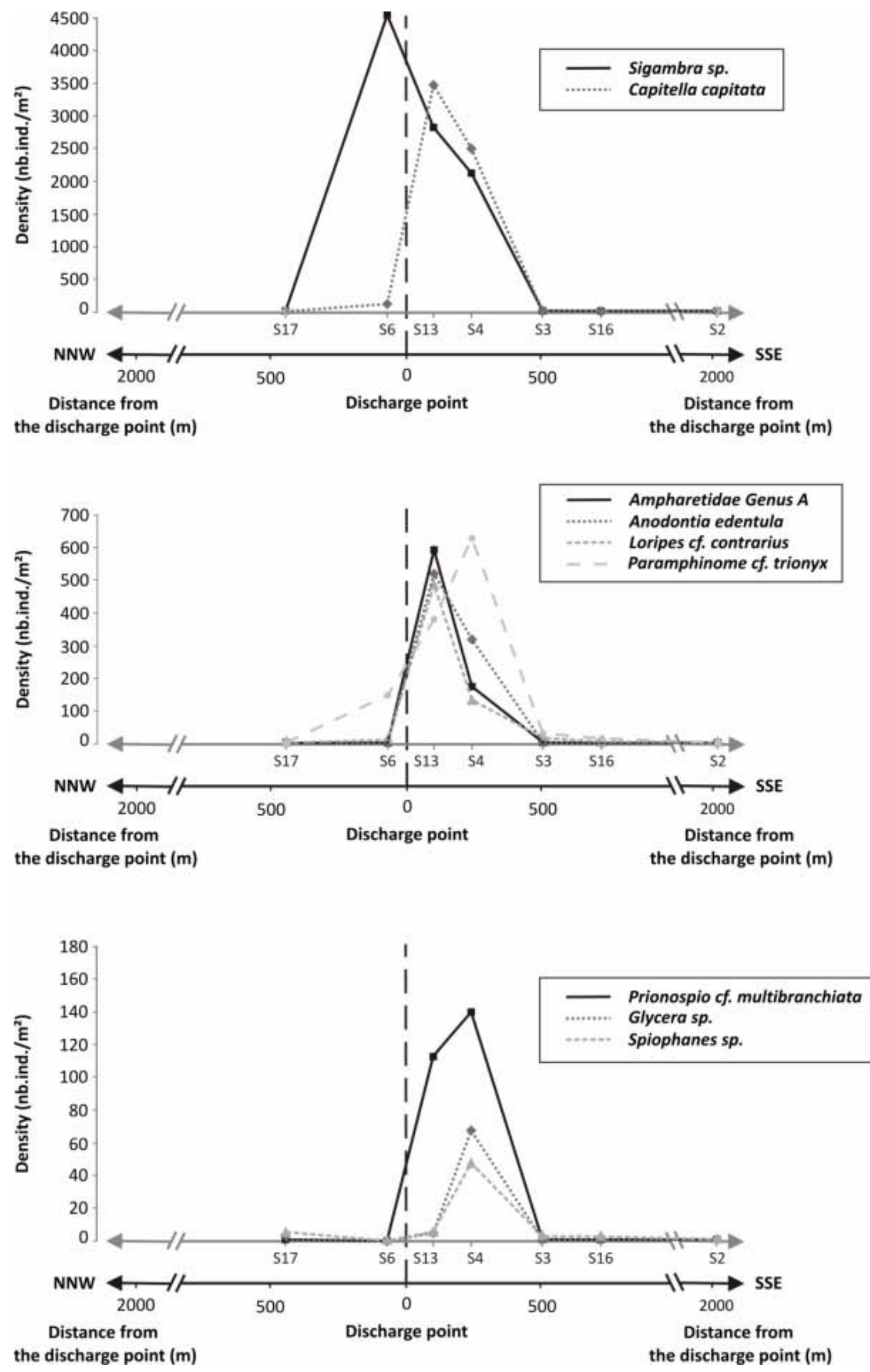

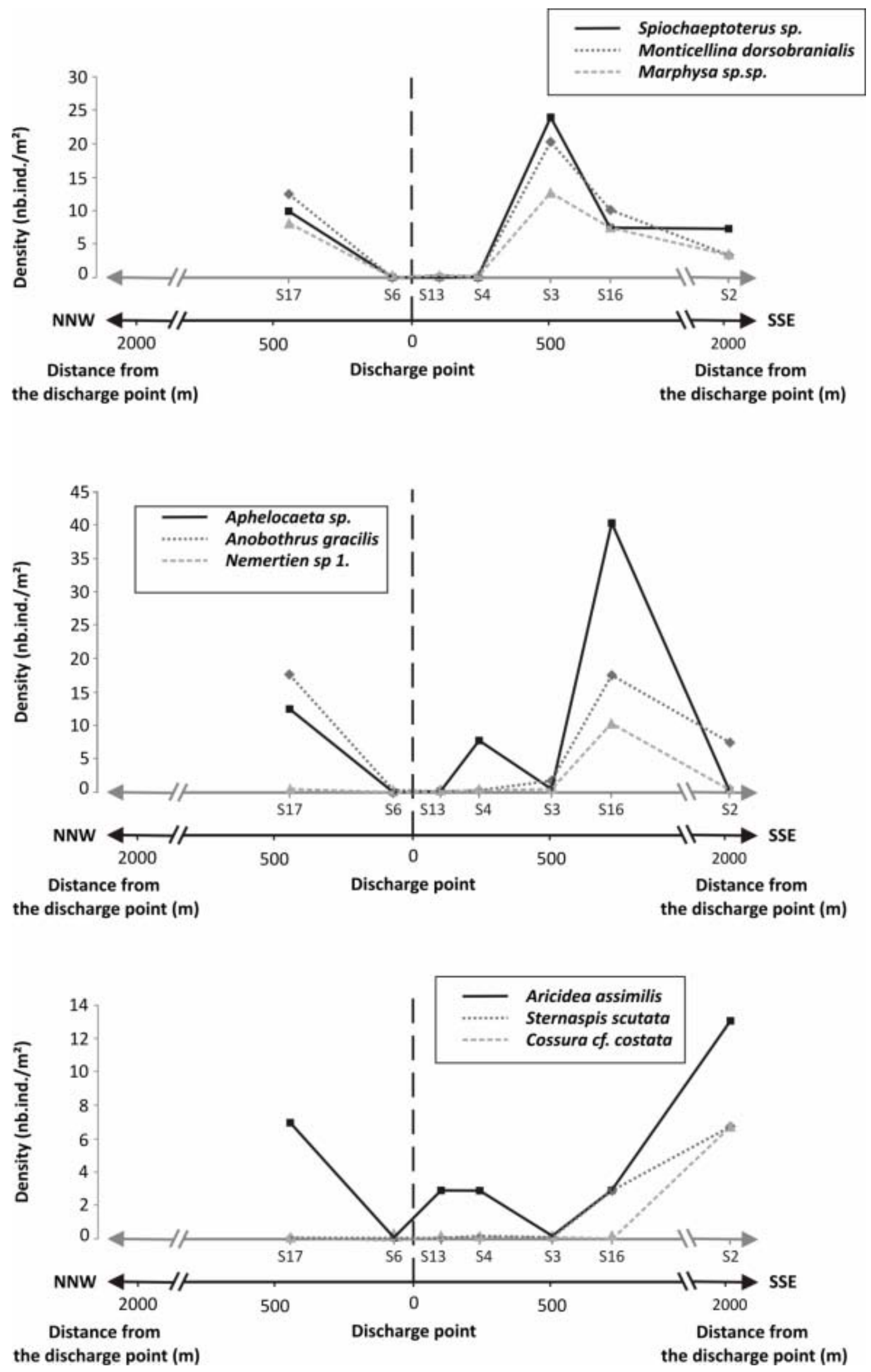
Fig. 10. Average densities of the 18 macrofauna indicator species (number of individuals per $\mathrm{m}^{2}$ ) at the 7 stations sampled in 2003 

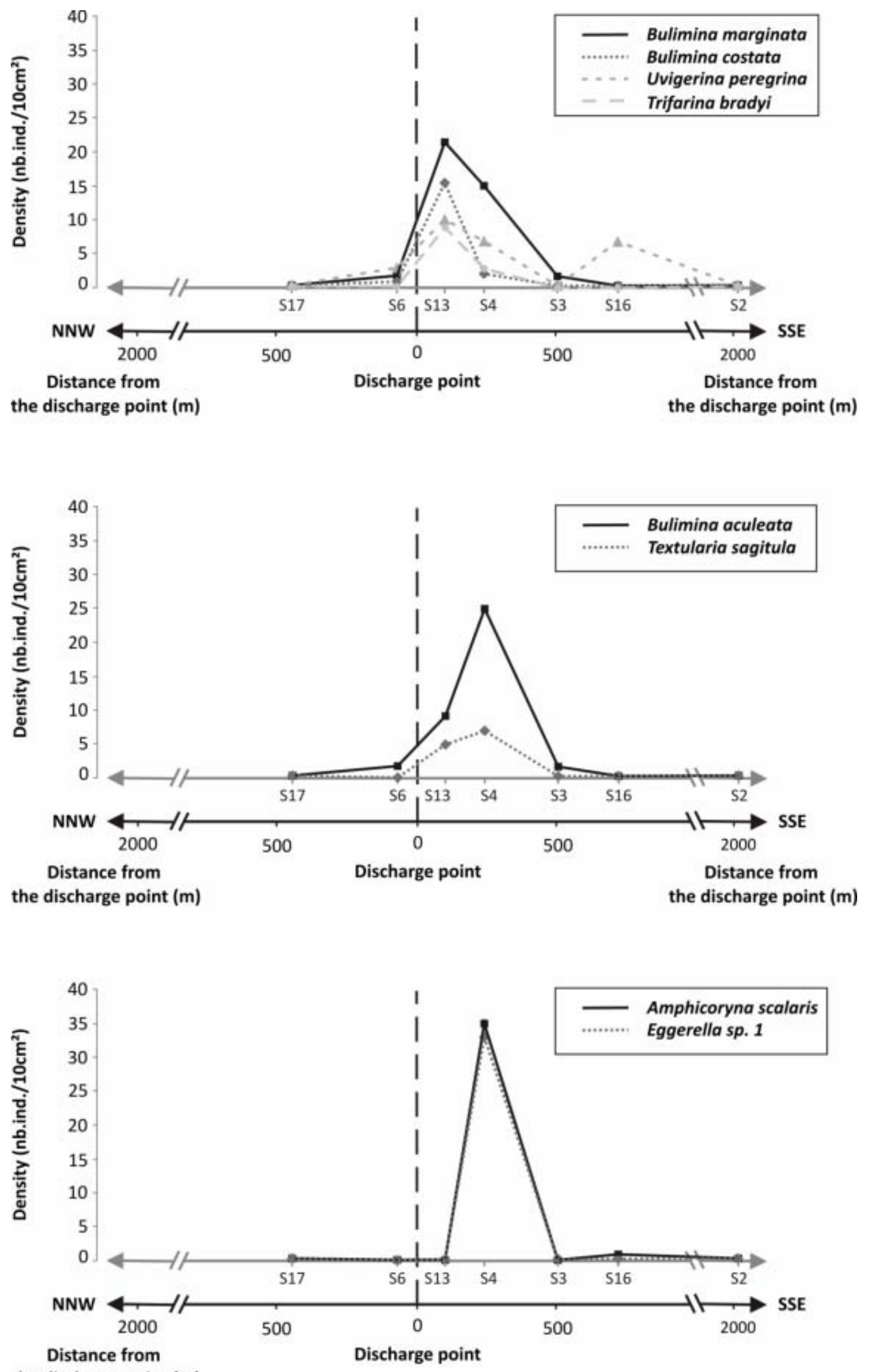
Fig. 11. Total densities of the 7 foraminifera indicator species from the fraction $>150 \mu \mathrm{m}$ (number of individuals per $10 \mathrm{~cm}^{2}$ ) at the 7 stations sampled in 2003 

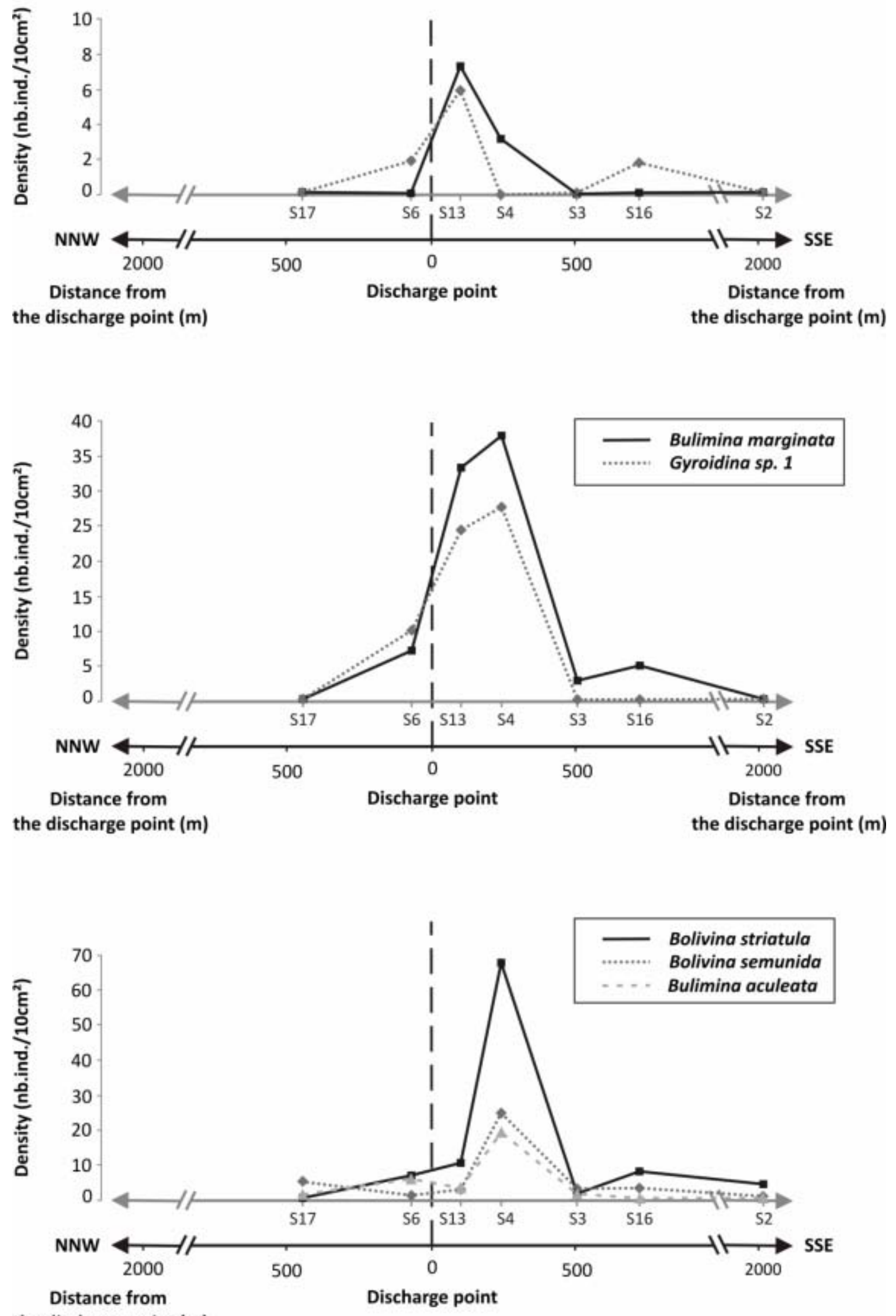

the discharge point ( $m$ ) 
Fig. 12. Total densities of the 7 foraminifera indicator species from the fraction 63$150 \mu \mathrm{m}$ (number of individuals per $10 \mathrm{~cm}^{2}$ ) at the 7 stations sampled in 2003

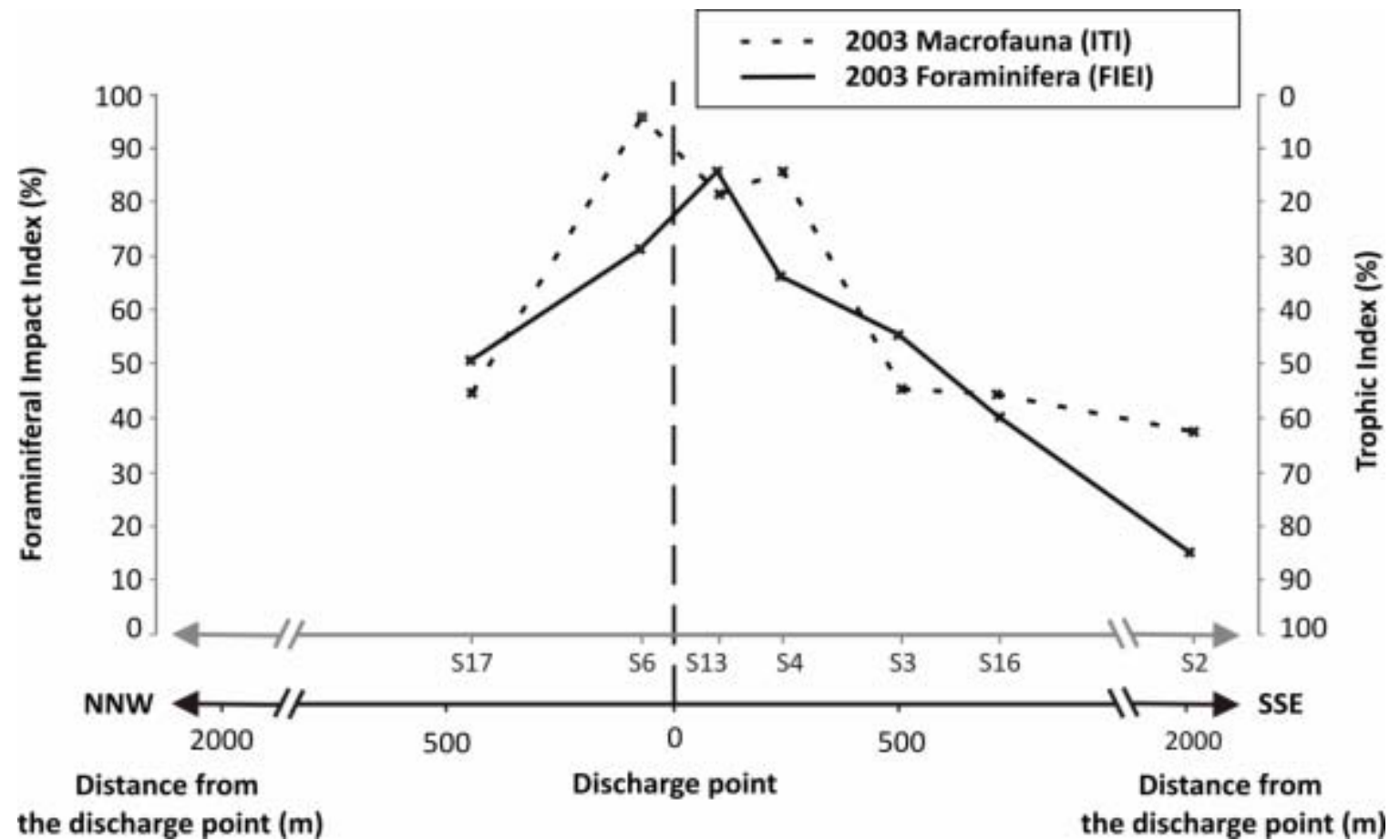

Fig. 13. Values of the ITI (in \%) applied to the macrofauna and the FIEI (in \%) applied to the foraminifera at the 7 stations sampled in 2003

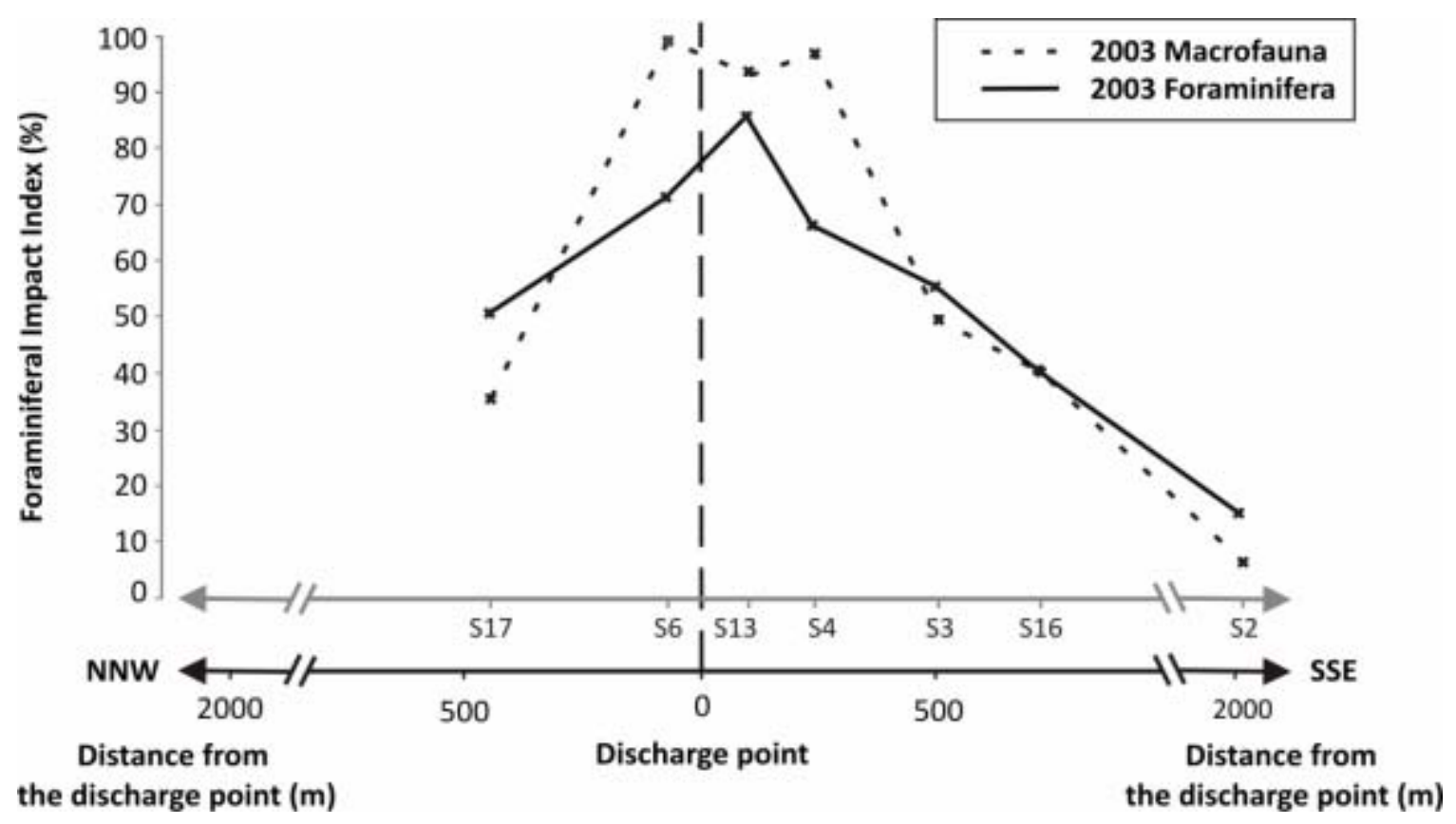

Fig. 14. Values of the FIEI (in \%) applied to the macrofauna and foraminifera at the 7 stations sampled in 2003 